\title{
Ecological history affects zooplankton community responses to acidification
}

Janet M. Fischer

Jennifer L. Klug

Fairfield University, jklug@fairfield.edu

Anthony R. Ives

Thomas M. Frost

Follow this and additional works at: https://digitalcommons.fairfield.edu/biology-facultypubs Copyright 2001 Ecological Society of America

The final publisher PDF has been archived here with permission from the copyright holder.

\section{Peer Reviewed}

\section{Repository Citation}

Fischer, Janet M.; Klug, Jennifer L.; Ives, Anthony R.; and Frost, Thomas M., "Ecological history affects zooplankton community responses to acidification" (2001). Biology Faculty Publications. 42. https://digitalcommons.fairfield.edu/biology-facultypubs/42

\section{Published Citation}

Fischer, J. M., Klug, J. L., Ives, A. R., \& Frost, T. M. (2001). Ecological history affects zooplankton community responses to acidification. Ecology, 82(11), 2984-3000.

This item has been accepted for inclusion in DigitalCommons@Fairfield by an authorized administrator of DigitalCommons@Fairfield. It is brought to you by DigitalCommons@Fairfield with permission from the rightsholder(s) and is protected by copyright and/or related rights. You are free to use this item in any way that is permitted by the copyright and related rights legislation that applies to your use. For other uses, you need to obtain permission from the rights-holder(s) directly, unless additional rights are indicated by a Creative Commons license in the record and/or on the work itself. For more information, please contact digitalcommons@fairfield.edu. 


\title{
ECOLOGICAL HISTORY AFFECTS ZOOPLANKTON COMMUNITY RESPONSES TO ACIDIFICATION
}

\author{
Janet M. Fischer, ${ }^{1,3}$ Jennifer L. Klug, ${ }^{2}$ Anthony R. Ives, ${ }^{2}$ and Thomas M. Frost ${ }^{1,4}$ \\ ${ }^{1}$ Center for Limnology, University of Wisconsin, 680 North Park Street, Madison, Wisconsin 53706 USA \\ ${ }^{2}$ Department of Zoology, University of Wisconsin, 430 Lincoln Drive, Madison, Wisconsin 53706 USA
}

\begin{abstract}
The effects of ecological history are frequently ignored in attempts to predict community responses to environmental change. In this study, we explored the possibility that ecological history can cause differences in community responses to perturbation using parallel acidification experiments in three sites with different $\mathrm{pH}$ histories in the Northern Highland Lake District of Wisconsin, USA. In Trout Lake, high acid neutralizing capacity had historically buffered changes in $\mathrm{pH}$. In contrast, the two basins of Little Rock Lake (Little Rock-Reference and Little Rock-Treatment) had experienced seasonal fluctuations in $\mathrm{pH}$. Furthermore, the two lake basins were separated with a curtain and Little RockTreatment was experimentally acidified in the late 1980s. In each site, we conducted mesocosm experiments to compare zooplankton community dynamics in control (ambient $\mathrm{pH}$ ) and acidified ( $\mathrm{pH}$ 4.7) treatments. Zooplankton community responses were strongest in Trout Lake and weakest in Little Rock-Treatment suggesting that ecological history affected responses to acidification. In part, variation in community sensitivity to acidification was driven by differences in species composition. However, the results of a reciprocal transplant experiment indicated that changes in the acid tolerance of populations during past acidification events may make zooplankton communities less sensitive to subsequent $\mathrm{pH}$ stress. Our study highlights the role that ecological history may play in community-level responses to environmental change.
\end{abstract}

Key words: acidification; community dynamics; community structure; ecological history; freshwater zooplankton; Northern Highland Lake District, Wisconsin; rapid evolution.

\section{INTRODUCTION}

One of the challenges in developing a predictive understanding of community responses to perturbations is that relatively similar communities can vary substantially in their responses to a given perturbation. For example, effects of drought on old-field plant communities can vary strongly among sites with different species richness (Tilman 1996). Similarly, Menge et al. (1994) found that removal of the predator Pisaster had stronger effects on marine invertebrate communities in sites that were exposed to wave action than in more sheltered sites. Thus, within a particular type of ecosystem, among-site variation in community-level responses to natural and experimental perturbations can be substantial. In this study, we examine the role of ecological history in generating variation in community responses to perturbation by comparing zooplankton responses to experimental acidification in three sites with contrasting histories.

Historical events have been shown to have lasting effects on a wide variety of ecological systems includ-

Manuscript received 7 February 2000; revised 27 October 2000; accepted 20 November 2000; final version received 13 December 2000.

${ }^{3}$ Present address: Department of Biology, Franklin and Marshall College, Lancaster, Pennsylvania 17604-3003 USA. E-mail: j_fischer@acad.fandm.edu

${ }_{4}$ Deceased. ing shortgrass prairies (Jaramillo 1988), old-growth forests (Foster 1988), and coral reefs (Hughes 1989). However, the effects of ecological legacies on community and ecosystem responses to a changing environment are not widely recognized (Holt 1995, McPeek and Miller 1996). If historical conditions strongly influence community and ecosystem responses to environmental change, then explicit consideration of ecological history may improve forecasting of ecological responses to environmental change and guide identification of highly sensitive systems.

In some cases, stressful environmental conditions in the recent past can increase ecological sensitivity to subsequent perturbation (Peterson and Black 1988, Death 1996). For example, bivalve mussel communities that have been recently subjected to crowding exhibit increased sensitivity to subsequent physical stress (Peterson and Black 1988). Past environmental conditions may also reduce future community responses to the same perturbation by changing the species composition of a community toward a more tolerant assemblage. Examples where this mechanism plays a role in determining community sensitivity to perturbation include fish community responses to winterkill (Tonn and Magnuson 1982) and vegetation responses to fire (Muir 1993, Turner et al. 1997).

Natural selection caused by particular environmental perturbations may also alter responses of the com- 
Plate 1. Aerial photograph of the Northern Highland Lake District of Wisconsin (USA) showing the study sites. Trout Lake is in the upper right, and Little Rock Lake is in the lower left.

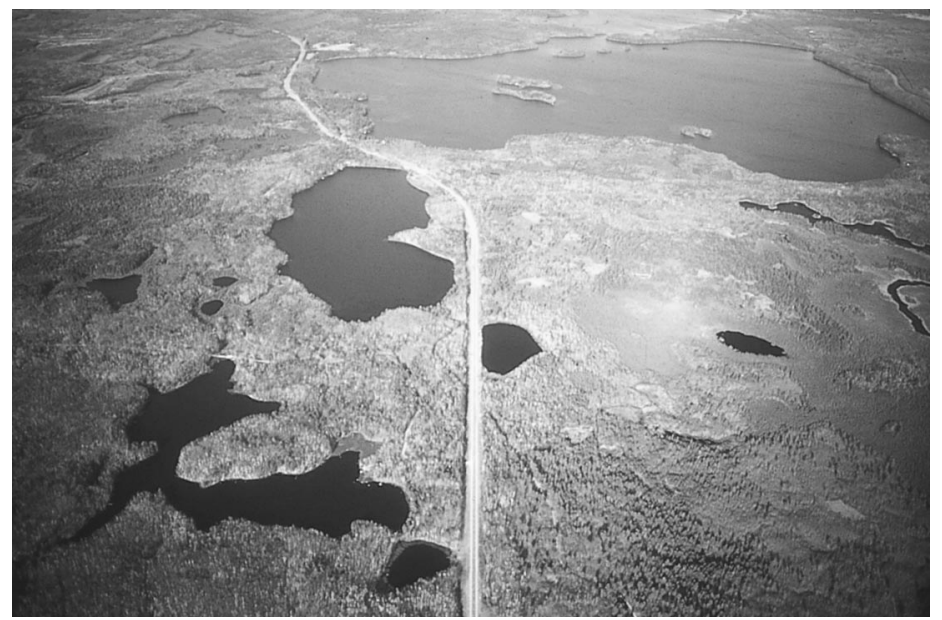

munity to a repeated perturbation by increasing the tolerance of populations that persist. The literature contains numerous cases of evolution in field populations of a single species subjected to selection. Examples of adaptive variation within a species include plant responses to lead (Wu and Antonovics 1976), fish and aquatic plant responses to extreme thermal environments (Christy and Sharitz 1980, Smith et al. 1983), bird responses to drought (Price et al. 1984), oligochaete responses to heavy metals (Klerks and Levinton 1989), caterpillar responses to insecticide (Carriere et al. 1995), fish responses to predators (Reznick et al. 1997), and zooplankton responses to fish predation (Hairston and Dillon 1990). Interestingly, many of these examples involve responses to anthropogenic environmental changes that generated strong selective forces (Bishop and Cook 1981).

Despite extensive evidence for rapid evolution in some populations, the consequences of evolutionary changes for community- and/or ecosystem-level sensitivity to perturbation have not been demonstrated. Can evolutionary changes affect community- and ecosystem-level responses to a changing environment? If so, can these evolutionary changes occur on relatively short time scales that are relevant to ecological dynamics? Answers to these questions are important for determining whether ecologists need to incorporate rapid evolution in their predictions about the ecological impacts of environmental changes such as climate change, $\mathrm{UV}$, and pollutants.

The goal of our study was to examine the role of history in controlling zooplankton community responses to acidification. Previous work conducted at a variety of spatial and temporal scales has demonstrated strong effects of acidification on zooplankton communities (e.g., Frost and Montz 1988, Schindler et al. 1991, Locke and Sprules 1993). To examine the effects of acidification history on zooplankton responses to current acidification events, we used a comparative experimental approach (sensu Menge et al. 1994) in which identically designed, replicated mesocosm experiments were conducted simultaneously in three study sites. Our study sites included a highly buffered site, which was characterized by high and stable $\mathrm{pH}$, a site that had been experimentally acidified during the 1980 s, and a site that had intermediate levels of natural $\mathrm{pH}$ fluctuations representing a midpoint between the two extremes occurring in the other sites. In each study site, we contrasted zooplankton community dynamics in control (ambient $\mathrm{pH})$ and acidified $(\mathrm{pH} 4.7)$ treatments. Comparison of zooplankton community responses in the three sites allowed us to examine the generality of community changes following acidification and to explore the role of history in determining community sensitivity to acidification. Specifically, we tested the hypothesis that acidification history affects community-level sensitivity to experimental acidification. We found that community-level sensitivity varied substantially among sites due to differences in species composition among sites, as well as population differences in acid tolerance.

We conducted two additional shorter term experiments to investigate the relationship between zooplankton sensitivity and acidification history in more detail. First, we conducted an experiment wherein zooplankton from each study site were exposed to a range of reduced $\mathrm{pH}$ conditions for one week. We expected zooplankton from each site to decline when exposed to conditions more acidic than historical conditions. Second, we examined the importance of zooplankton population differences and environmental factors in determining sensitivity to acidification using a reciprocal transplant experiment. Here, we present experimental evidence that history affects community-level responses to environmental change via changes in community composition and changes in population tolerance.

\section{Methods \\ Study sites}

Our three study sites were located in the Northern Highland Lake District of Wisconsin, USA (see Plate 
1). Despite their close proximity, the sites differed substantially in acidification history. Trout Lake $\left(46^{\circ} 02^{\prime}\right.$ $\mathrm{N}, 89^{\circ} 40^{\prime} \mathrm{W}$, area, 1608 ha; mean depth, $\left.15 \mathrm{~m}\right)$ is relatively well-buffered (acid neutralizing capacity [ANC], $829 \mu \mathrm{mol} / \mathrm{L}$ ) and maintains a $\mathrm{pH}>8.0$. Located

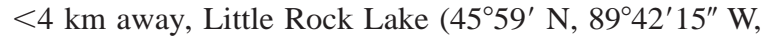
area, $18 \mathrm{ha}$; mean depth, $4 \mathrm{~m}$ ) is poorly buffered (ANC, $21 \mu \mathrm{mol} / \mathrm{L}$ ), has a mean ice-free season $\mathrm{pH}$ of 6.1 , and naturally experiences $\mathrm{pH}$ conditions $<5.4$ over the course of a year (Kratz et al. 1987). In 1984, the two basins of Little Rock Lake were divided with an inert vinyl curtain and, during the subsequent six years, the $\mathrm{pH}$ of the northern basin (henceforth Little Rock-Treatment) was reduced in three, 2-yr stages to 4.7 using sulfuric acid (Brezonik et al. 1986, 1993). The southern basin of Little Rock Lake (henceforth Little Rock-Reference) was maintained as an unmanipulated reference throughout the course of the experiment. After 1990, Little Rock-Treatment was allowed to recover naturally. Chemical recovery proceeded at roughly the same rate as the acidification (Sampson et al. 1995, Frost et al. 1998). Sampson et al. (1995) report the following mean ice-free season $\mathrm{pH}$ values during recovery: 1991, $5.1 \pm 0.05 ; 1992,5.2 \pm 0.04 ; 1993,5.3 \pm 0.06$; and $1994,5.5 \pm 0.11$. In 1995, at the time of the mesocosm experiment, the pH of Little Rock-Treatment (5.9) was similar to the $\mathrm{pH}$ (6.1) of the unacidified basin. In 1997, the year of the $\mathrm{pH}$ gradient and reciprocal transplant experiments, chemical recovery was virtually complete (mean surface $\mathrm{pH}$ was $6.2 \pm 0.13$ and $6.4 \pm 0.27$ during the ice-free season in Little Rock-Reference and Little Rock-Treatment, respectively).

While the three study sites exhibit striking differences in acidification history, other aspects of their water chemistry are quite similar. Nutrient concentrations in all three sites are characteristic of relatively unproductive lakes of the Northern Highland Lake District of Wisconsin (Trout Lake total nitrogen [TN], 235 $\mu \mathrm{g} / \mathrm{L}$; total phosphorus [TP], $16.9 \mu \mathrm{g} / \mathrm{L} ;{ }^{5}$ Little RockReference TN $=291 \mu \mathrm{g} / \mathrm{L}, \mathrm{TP}=13.1 \mu \mathrm{g} / \mathrm{L}$, Sampson 1992; Little Rock-Treatment $\mathrm{TN}=226 \mu \mathrm{g} / \mathrm{L}$, TP $=$ $13.0 \mu \mathrm{g} / \mathrm{L}$, Sampson 1992). Dissolved organic carbon (DOC) concentrations are $>3 \mathrm{mg} / \mathrm{L}$ in all sites. When lake water was acidified in our experiments, DOC concentrations remained $>2.8 \mathrm{mg} / \mathrm{L}$ in all sites. Estimates of the $1 \%$ attenuation depth of UV-B radiation based on published empirical relationships between DOC and UV-B penetration (Morris et al. 1995, Williamson et al. 1996) were always $<0.7 \mathrm{~m}$. Therefore, UV-B was probably not an important factor driving zooplankton responses to acidification in our experiments because our mesocosms were $4.5 \mathrm{~m}$ deep and the containers for our short-term experiments were incubated at a depth of $2 \mathrm{~m}$.

Zooplankton species composition was similar,

${ }^{5}$ URL: 〈http://limnosun.limnology.wisc.edu/map/lter_lake/tr text.html $\rangle$ though not identical, in the three study sites. In our mesocosm experiment, more than half of the dominant zooplankton species were present in all three sites. Five out of eight total crustacean zooplankton species were common to all three sites (Bosmina longirostris, Chydorus sphaericus, Holopedium gibberum, Sida crystallina, and Tropocyclops extensus). Little Rock-Reference and Little Rock-Treatment differed only in the presence/absence of one species (Diacyclops thomasi). Community similarity, calculated for all pairwise combinations of sites using Jaccard's Index (Mueller-Dombois and Ellenberg 1974) on presence/absence data for the mesocosm experiment described below, was relatively high for all combinations of study sites (mean, 74\%; range, 63-86\%). Frost et al. (1998) report that species lists of crustacean zooplankton and rotifers in the two basins of Little Rock Lake were identical in 1995. However, Trout Lake contained some species that are typically absent in more acidic lakes. For example, the dominant daphnid in Trout Lake (Daphnia mendotae, formerly Daphnia galeata mendotae) is absent from Little Rock and is generally absent from other lakes with $\mathrm{pH}<5.5$ (Keller et al. 1990).

\section{Mesocosm experiment}

To compare zooplankton community responses to acidification in Trout Lake, Little Rock-Reference, and Little Rock-Treatment, we conducted a mesocosm experiment from 19 June through 31 July 1995. In each site, two treatments were applied to in situ mesocosms containing zooplankton communities from the local site: (1) acidified, in which the $\mathrm{pH}$ was reduced to 4.7 \pm 0.2 , and (2) control with ambient $\mathrm{pH}$ conditions.

We considered several alternative approaches for creating the acidified treatment in this experiment including (A) adding the same amount of acid to each site, (B) manipulating $\mathrm{pH}$ by the same amount in each site, (C) manipulating hydrogen ions by the same amount in each site, and (D) dropping $\mathrm{pH}$ to the same level in each site. We decided against approach A because the sites differed in acid neutralizing capacity (see Methods: Study sites description) and, therefore, adding the same volume of acid would lead to very different acidity levels in each site. We eliminated approach $\mathrm{B}$ because this design does not account for the fact that $\mathrm{pH}$ is calculated as the logarithm of the inverse of hydrogen ion concentration and, therefore, ignores the fact that the physiological response of zooplankton to acidification is a response to hydrogen ions, not $\mathrm{pH}$ units. Our calculations show that the change in hydrogen ion concentration using approach B would be several orders of magnitude greater in Little Rock-Treatment than in Trout Lake (Table 1). Although approaches $\mathrm{C}$ and $\mathrm{D}$ differ in principle, they are not different in practice because our accuracy during $\mathrm{pH}$ manipulations in the field was limited to target $\mathrm{pH} \pm 0.2$. That is, the target $\mathrm{pH}$ for approach $\mathrm{C}$ where hydrogen ion concentration was changed by $2.00 \times 10^{-5}$ in each site 
TABLE 1. Comparison of alternative approaches (see Methods: Mesocosm experiment for explanation of approach A) for creating the acidified treatment in the mesocosm experiment.

\begin{tabular}{|c|c|c|c|c|c|}
\hline Approach & Site & Target $\mathrm{pH}$ & Target $\left[\mathrm{H}^{+}\right]$ & $\Delta \mathrm{pH}$ & $\Delta\left[\mathrm{H}^{+}\right]$ \\
\hline B) Manipulate $\mathrm{pH}$ by the same amount in each site & $\begin{array}{l}\text { TR } \\
\text { LR } \\
\text { LT }\end{array}$ & $\begin{array}{l}6 \\
4.1 \\
3.9\end{array}$ & $\begin{array}{l}1.00 \times 10^{-6} \\
7.94 \times 10^{-5} \\
1.26 \times 10^{-4}\end{array}$ & $\begin{array}{l}2 \\
2 \\
2\end{array}$ & $\begin{array}{l}9.90 \times 10^{-7} \\
7.86 \times 10^{-5} \\
1.25 \times 10^{-4}\end{array}$ \\
\hline C) Manipulate $\left[\mathrm{H}^{+}\right]$by the same amount in each site & $\begin{array}{l}\text { TR } \\
\text { LR } \\
\text { LT }\end{array}$ & $\begin{array}{l}4.70 \\
4.68 \\
4.67\end{array}$ & $\begin{array}{l}2.00 \times 10^{-5} \\
2.08 \times 10^{-5} \\
2.13 \times 10^{-5}\end{array}$ & $\begin{array}{l}3.30 \\
1.42 \\
1.23\end{array}$ & $\begin{array}{l}2.00 \times 10^{-5} \\
2.00 \times 10^{-5} \\
2.00 \times 10^{-5}\end{array}$ \\
\hline D) Drop $\mathrm{pH}$ to the same level in each site & $\begin{array}{l}\text { TR } \\
\text { LR } \\
\text { LT }\end{array}$ & $\begin{array}{l}4.7 \\
4.7 \\
4.7\end{array}$ & $\begin{array}{l}2.00 \times 10^{-5} \\
2.00 \times 10^{-5} \\
2.00 \times 10^{-5}\end{array}$ & $\begin{array}{l}3.30 \\
1.40 \\
1.20\end{array}$ & $\begin{array}{l}1.99 \times 10^{-5} \\
1.92 \times 10^{-5} \\
1.87 \times 10^{-5}\end{array}$ \\
\hline
\end{tabular}

Notes: Bold values indicate the factor held constant across sites in each design. Target $\mathrm{pH}\left(\left[\mathrm{H}^{+}\right]\right)$indicate $\mathrm{pH}\left(\left[\mathrm{H}^{+}\right]\right)$values in the acidified treatment, whereas $\Delta \mathrm{pH}\left(\Delta\left[\mathrm{H}^{+}\right]\right)$indicate the difference in $\mathrm{pH}\left(\left[\mathrm{H}^{+}\right]\right)$between control and acidified treatments. Sites codes are TR, Trout Lake; LR, Little Rock-Reference; and LT, Little Rock-Treatment.

would range from 4.67-4.69 and we could not manipulate $\mathrm{pH}$ with that level of accuracy. Similarly, for approach $\mathrm{D}$, our calculations reveal that the absolute change in hydrogen ion concentration was similar among study sites (Table 1). In fact, if we had chosen to change hydrogen ion concentration by $1.87 \times 10^{-5}$ in all sites, the target $\mathrm{pH}$ for acidified treatments in Trout Lake would have been $\mathrm{pH} 4.73$ (note that this value lies well within our target of $\mathrm{pH} 4.7 \pm 0.2$ ). Thus, our manipulations of $\mathrm{pH}$ to a final target $4.7 \pm 0.2$ are appropriate for comparing zooplankton community sensitivity among sites.

Mesocosms (2000 L, $0.8 \mathrm{~m}$ diameter, $4 \mathrm{~m}$ deep) were constructed of clear polyethylene cylinders, sealed at the bottom, and suspended from wooden rafts. Mesocosms were filled with lake water pumped from $2 \mathrm{~m}$ depth. Because pumping can impose high mortality for some zooplankton species, water was passed through an 80- $\mu \mathrm{m}$ mesh net to remove zooplankton, and mesocosms were then restocked with zooplankton at ambient lake density using net tows $(80-\mu \mathrm{m}$ mesh) taken through the entire water column at dusk.

Zooplankton were allowed to acclimate for $1 \mathrm{wk}$ and initial samples were collected before treatments were imposed. Water was acidified to the target level of $\mathrm{pH}$ 4.7 ( \pm 0.2$)$ using sulfuric acid. Each treatment (control and acidified) was replicated three times. During the experiment, $\mathrm{pH}$ was monitored twice a week and adjusted to the target level when necessary. Following each acid addition, all mesocosms (including controls) were mixed thoroughly.

Zooplankton were sampled weekly using a 12-L Schindler Patalas trap equipped with an $80-\mu \mathrm{m}$ mesh net. Samples were collected at four depths $(0.5,1.5$, 2.5 , and $3.5 \mathrm{~m}$ ), pooled to form a single sample, and preserved in cold $5 \%$ sucrose-buffered formalin. One quarter of each sample was counted at $50 \times$ on a dissecting microscope. Due to the difficulties of accurately identifying copepod nauplii and early stage copepodites to species, these stages were not included in our analyses. Later stage copepodites and adult copepods were lumped for analyses. Here, we report on the dy- namics of the dominant crustacean zooplankton taxa. We considered dominant taxa to include any species that constituted $>5 \%$ of the total crustacean zooplankton community by biomass or abundance on any date in either treatment. Although rotifers can also exhibit interesting responses to acidification (e.g., Gonzalez and Frost 1994), we have excluded rotifers from our analyses in order to simplify the presentation of responses of multiple zooplankton species from several experiments in three study sites.

Zooplankton population densities were converted to biomass using measured lengths and published lengthmass regressions (McCauley 1984, Peters and Downing 1984). Total zooplankton biomass was calculated as the sum of the biomass of the dominant species. For each sample date, we assessed differences in zooplankton community composition between control and acidified treatments using a proportional similiarity index:

$$
1-0.5 \sum_{i=1}^{S}\left|p_{\mathrm{c} i}-p_{\mathrm{ai}}\right|
$$

(after Schoener 1970) where $S$ is the total number of dominant species, $p_{\mathrm{c} i}$ is the mean proportion of species $i$ in the control treatment, and $p_{\mathrm{a} i}$ is the mean proportion of species $i$ in the acidified treatment. Biomass data were used to avoid bias due to small, but numerically abundant taxa.

Zooplankton responses to acidification were analyzed using univariate repeated-measures ANOVA. Population densities were square $\operatorname{root}(x+1 / 2)$ transformed, and total zooplankton biomass was $\ln (x+1)$ transformed to normalize data and homogenize variance. To assess time effects and time by treatment interactions, we used the Huynh-Feldt adjustment for departure from sphericity. Departure from sphericity arises in time series data because adjacent time points are more tightly correlated than distant time points (von Ende 1993). For zooplankton population responses, we applied a sequential Bonferroni correction for the number of species analyzed in each study site to assess the significance of ANOVA results. We excluded one con- 
trol mesocosm in Trout Lake from our analyses due to dramatic declines in all large-bodied zooplankton species suggesting contamination by fish.

\section{pH gradient experiment}

To explore further the relationship between acidification history and zooplankton sensitivity to acidification, we conducted a short-term experiment in July 1997 where zooplankton from each study site were exposed to a range of reduced $\mathrm{pH}$ conditions for one week. Because the generation times of most crustacean zooplankton species in north temperate lakes exceed one week, we assumed that changes in density during this experiment primarily reflected direct effects of acidification (i.e., effects of acidification that were independent of species interactions among zooplankton). We expected sensitivity to exhibit the following pattern: Trout Lake $>$ Little Rock-Reference $>$ Little Rock-Treatment. For each site, experimental treatments included ambient pH, pH 5.3, pH 4.7, and $\mathrm{pH}$ 4.0. Each treatment was replicated three times.

In each site, integrated water-column samples were collected from the epilimnion using a tube sampler (5 $\mathrm{cm}$ diameter, $2.25 \mathrm{~m}$ long) and passed through an 80$\mu \mathrm{m}$ mesh net to remove zooplankton. Water was acidified to target levels $( \pm 0.1)$ using sulfuric acid. Transparent polyethylene containers $(10 \mathrm{~L}$ volume) were filled with water of the appropriate $\mathrm{pH}$ and stocked with zooplankton at approximately lake densities. Zooplankton were collected from each site using net tows (80- $\mu \mathrm{m}$ mesh).

After $1 \mathrm{wk}$ of incubation in the lake at $2 \mathrm{~m}$ depth, containers were collected and the contents were filtered through an $80-\mu \mathrm{m}$ mesh net and preserved in $95 \%$ ethanol. Zooplankton were counted in toto at $50 \times$ on a dissecting microscope. Zooplankton population densities were $\ln (x+1)$ transformed to normalize data and homogenize variance. Transformed data were analyzed using one-Way ANOVA to test for an overall $\mathrm{pH}$ effect. For species where ANOVA indicated a significant treatment effect, we used Dunnett's contrasts to test for significant decreases in population density in each acidified treatment compared to the control. We excluded 2 of the 36 containers from the analysis due to contamination with larval fish and vandalism. While we did not specifically quantify periphyton growth, we did not observe any periphyton inside the experimental containers at the end of the 7-d incubation.

\section{Reciprocal transplant experiment}

Differences in sensitivity to acidification such as those observed in the mesocosm and $\mathrm{pH}$ gradient experiment (see Results) could be caused by zooplankton population differences and/or environmental conditions that might differ among sites. For example, environmental conditions may play a role if food resources for zooplankton decline more with acidification in some lakes than in others. To examine the relative importance of zooplankton population differences and environmental factors, it is necessary to conduct a reciprocal transplant experiment where the site of zooplankton origin and the environmental conditions are manipulated in a full factorial design (see Via 1994, Reznick and Travis 1996). We employed a $3 \times 3 \times 2$ factorial design where the factors were zooplankton source (Trout Lake, Little Rock-Reference, and Little Rock-Treatment), water source (Trout Lake, Little Rock-Reference, and Little Rock-Treatment), and $\mathrm{pH}$ (ambient $\mathrm{pH}$ and $\mathrm{pH}$ 4.7). The response variable in this experiment was the change in density during the 1-wk incubation. Change in density (rho) was calculated as $\ln \left(N_{\mathrm{f}}\right)-\ln \left(N_{\mathrm{i}}\right)$ where $N_{\mathrm{f}}$ and $N_{\mathrm{i}}$ are final and initial densities. Three replicates were employed per treatment yielding 54 total experimental units. Methods and experiment duration for the reciprocal transplant experiment were the same as the $\mathrm{pH}$ gradient experiment. As in the $\mathrm{pH}$ gradient experiment, we assumed that changes in population density during the 1-wk incubation were driven primarily by direct effects. We excluded 7 of the 54 containers from the analysis due to contamination with the invertebrate predator Chaoborus.

For species that occurred in more than one study site, we used three-way ANOVA to evaluate effects of $\mathrm{pH}$, zooplankton source, and water source on the change in zooplankton population density (i.e., $\ln \left(N_{\mathrm{f}}\right)$ $\left.-\ln \left(N_{\mathrm{i}}\right)\right)$. The statistical model tested for main effects of zooplankton source, water source, $\mathrm{pH}$, and all twoand three-way interactions between these variables. Our primary interest in interpreting this statistical model was in three effects: (1) water source $\times \mathrm{pH}$, (2) zooplankton source $\times \mathrm{pH}$, and (3) zooplankton source $\times$ water source $\times \mathrm{pH}$. These three effects allowed us to ask whether zooplankton responses to $\mathrm{pH}$ were affected by the site of population origins and/or local environmental conditions (Via 1994, Reznick and Travis 1996). Significant effects of zooplankton source $X$ $\mathrm{pH}$ and/or zooplankton source $\times$ water source $\times \mathrm{pH}$ indicate zooplankton population differences in acid sensitivity. Similarly, significant effects of water source $\times \mathrm{pH}$ and/or zooplankton source $\times$ water source $\times \mathrm{pH}$ indicate that local environmental conditions affect zooplankton responses to acid.

If the three-way ANOVA indicated a significant zooplankton source by $\mathrm{pH}$ interaction or a significant threeway interaction, we then used two-way ANOVA to test for $\mathrm{pH}$ and water effects for each zooplankton source separately to verify that patterns of sensitivity corresponded with acidification history as in our other experiments. The response variable in this experiment, rho $=\ln \left(N_{\mathrm{f}}\right)-\ln \left(N_{\mathrm{i}}\right)$, is conceptually similar to the numerator of population growth rate $(r)$; however, they are not equivalent because $N_{\mathrm{f}}$ and $N_{\mathrm{i}}$ in rho only include stages that could be readily identified to species. For copepods, $N_{\mathrm{f}}$ and $N_{\mathrm{i}}$ include later stage copepodites and adults. Therefore, $N_{\mathrm{f}}$ in our experiment is determined 

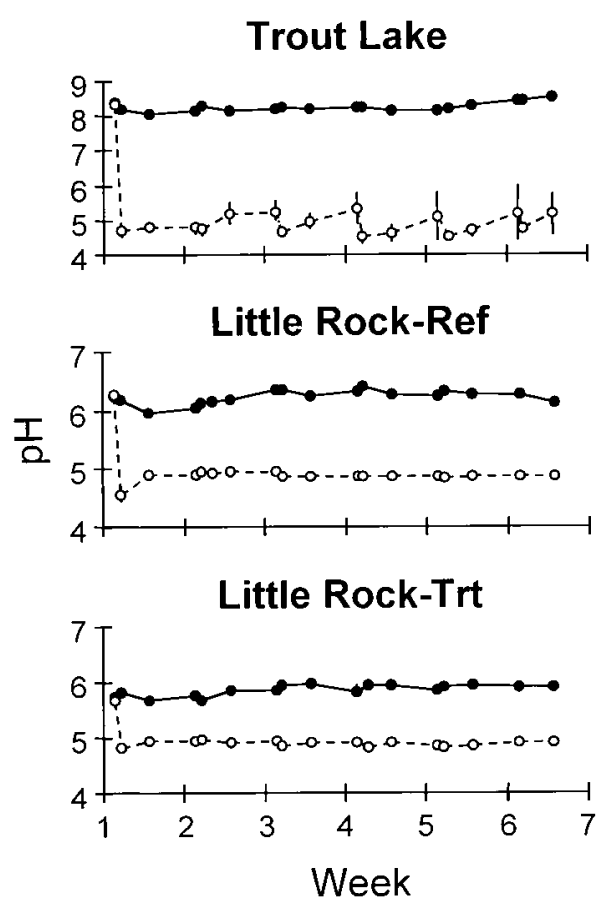

FIG. 1. The $\mathrm{pH}$ in the mesocosm experiment for Trout Lake, Little Rock-Reference, and Little Rock-Treatment. Means are plotted for control (solid circle) and acidified (open circle) treatments. Vertical bars indicate $\pm 1 \mathrm{SE}$. Ambient $\mathrm{pH}$ values in the study lakes during the same period were 8.4 , 6.1, and 5.8 in Trout Lake, Little Rock-Reference, and Little Rock-Treatment, respectively.

by two factors: (1) survival of later stage copepodites and adults, which were present in the initial sample and (2) maturation of nauplii and early stage copepodites, which were present in the initial sample but not identified to species. For this reason, it is not appropriate to compare rho across different zooplankton sources because differences in rho may arise due to factors like variation in the age structure of populations at the time of stocking. To assess acid sensitivity of populations from different sources, we compared rho at ambient $\mathrm{pH}$ to rho at $\mathrm{pH} 4.7$ for a given population. A population was considered to be acid sensitive if rho under acid conditions was significantly lower than rho at ambient $\mathrm{pH}$.

\section{Statistical analysis}

Statistical analyses for the mesocosm experiment and the reciprocal transplant experiment were conducted using SAS for Windows, version 6.12 (SAS 1990), whereas analysis for the $\mathrm{pH}$ gradient experiment was conducted using SYSTAT, version 5.2.1, for the Macintosh (Wilkinson et al. 1992)

\section{RESULTS}

\section{Mesocosm experiment}

In all three study sites, target $\mathrm{pH}$ levels $( \pm 0.2)$ were achieved in the acidified treatment while $\mathrm{pH}$ values in control bags were similar to ambient lake $\mathrm{pH}$ (Fig. 1). Variability in the acidified treatment in Trout Lake was caused by drift toward higher $\mathrm{pH}$ in one of three replicate bags. We believe that this bag must have had a small hole, but we have retained this replicate in our analysis because zooplankton abundance in this bag was not different from the other two replicates.

Although zooplankton community dynamics were affected by acidification in all three study sites, zooplankton community responses were strongest in Trout Lake and weakest in Little Rock-Treatment. Over the course of the experiment, zooplankton community structure in control and acidified treatments diverged most in Trout Lake and least in Little Rock-Treatment (Fig. 2). It is notable that community similarity between control and acidified treatments declined over
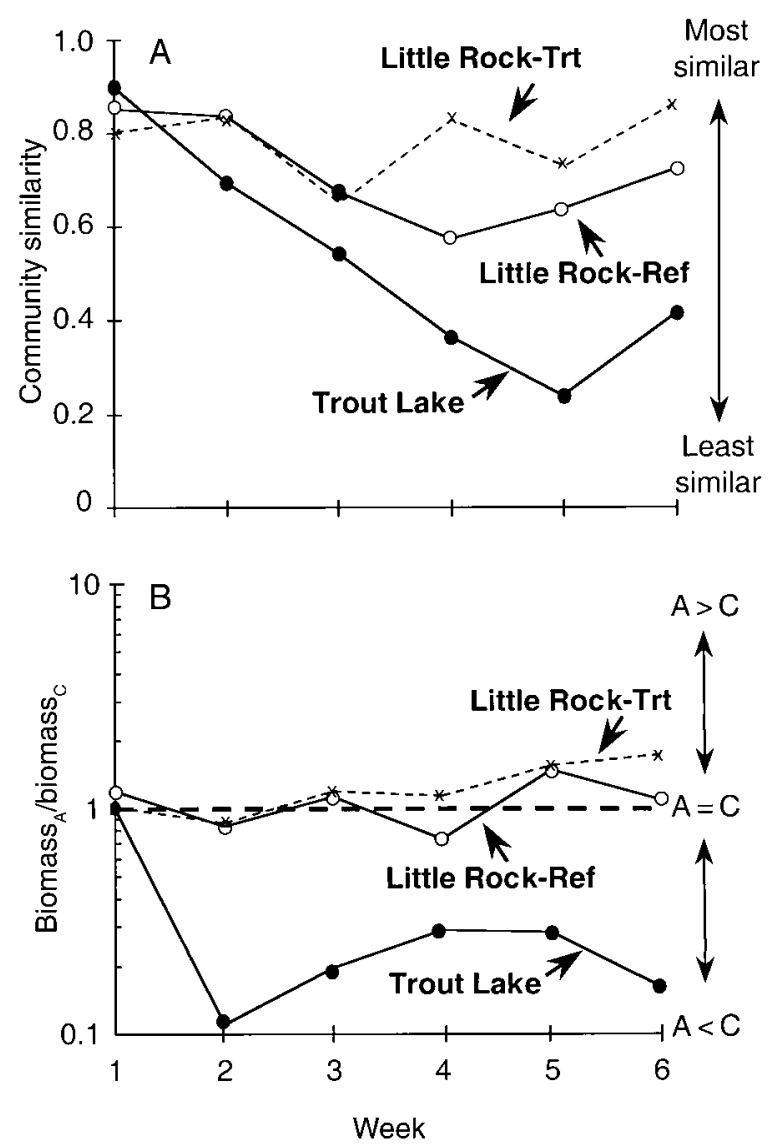

FIG. 2. Divergence in (A) community structure and (B) total zooplankton biomass between control (C) and acidified (A) treatments in the mesocosm experiment in Trout Lake, Little Rock-Reference, and Little Rock-Treatment. Community similarity was calculated using a proportional similarity index. We present differences in total zooplankton biomass as the ratio of mean biomass in the acidified and control treatments for each site. Because the ratio is presented on a $\log$ scale, the ratio represents a proportional difference in biomass, and ratios $<1$ indicate that biomass was reduced with acidification compared to the control. Note that the raw biomass data were used in the univariate repeated-measures ANOVA presented in Table 2. 
TABLE 2. Univariate repeated-measures ANOVA for zooplankton responses to acidification in the mesocosm experiment.

\begin{tabular}{|c|c|c|c|c|c|c|c|c|c|}
\hline \multirow[b]{2}{*}{ Species } & \multicolumn{3}{|c|}{$\mathrm{pH}$ treatment } & \multicolumn{3}{|c|}{ Time } & \multicolumn{3}{|c|}{ Time $\times \mathrm{pH}$ treatment } \\
\hline & df & $F$ & $P$ & df & $F$ & $P$ & df & $F$ & $P$ \\
\hline \multicolumn{10}{|l|}{ Trout Lake } \\
\hline Bosmina longirostris & 1,3 & 2.26 & 0.230 & 5,15 & 6.53 & 0.009 & 5,15 & 8.67 & 0.004 \\
\hline Chydorus sphaericus & 1,3 & 0.71 & 0.460 & 5,15 & 5.56 & 0.012 & 5,15 & 1.27 & 0.339 \\
\hline Daphnia mendotae & 1,3 & 83.74 & 0.003 & 5,15 & 62.83 & $<0.001$ & 5,15 & 31.21 & $<0.001$ \\
\hline Holopedium gibberum & 1,3 & 2.58 & 0.207 & 5,15 & 7.04 & 0.003 & 5,15 & 11.75 & $<0.001$ \\
\hline Sida crystallina & 1,3 & 0.82 & 0.433 & 5,15 & 6.34 & 0.006 & 5,15 & 2.15 & 0.138 \\
\hline Diacyclops thomasi & 1,3 & 19.34 & 0.022 & 5,15 & 4.03 & 0.018 & 5,15 & 1.61 & 0.219 \\
\hline Tropocyclops extensus & 1,3 & 129.24 & 0.002 & 5,15 & 40.37 & $<0.001$ & 5,15 & 15.95 & $<0.001$ \\
\hline Zooplankton biomass & 1,3 & 458.33 & $<0.001$ & 5,15 & 21.18 & $<0.001$ & 5,15 & 4.55 & 0.010 \\
\hline \multicolumn{10}{|l|}{ Little Rock-Reference } \\
\hline Bosmina longirostris & 1,4 & 14.81 & 0.018 & 5,20 & 7.82 & 0.003 & 5,20 & 2.51 & 0.107 \\
\hline Chydorus sphaericus & 1,4 & 2.49 & 0.190 & 5,20 & 29.00 & $<0.001$ & 5,20 & 2.91 & 0.110 \\
\hline Holopedium gibberum & 1,4 & 8.03 & 0.047 & 5,20 & 90.29 & $<0.001$ & 5,20 & 3.34 & 0.031 \\
\hline Sida crystallina & 1,4 & 1.50 & 0.287 & 5,20 & 16.69 & $<0.001$ & 5,20 & 0.90 & 0.463 \\
\hline Mesocyclops edax & 1,4 & 2.75 & 0.173 & 5,20 & 64.12 & $<0.001$ & 5,20 & 2.27 & 0.107 \\
\hline Tropocyclops extensus & 1,4 & 29.08 & 0.006 & 5,20 & 9.08 & $<0.001$ & 5,20 & 4.48 & 0.007 \\
\hline Zooplankton biomass & 1,4 & 0.41 & 0.558 & 5,20 & 10.09 & $<0.001$ & 5,20 & 1.00 & 0.442 \\
\hline \multicolumn{10}{|l|}{ Little Rock-Treatment } \\
\hline Bosmina longirostris & 1,4 & 41.06 & 0.003 & 5,20 & 42.48 & $<0.001$ & 5,20 & 2.34 & 0.134 \\
\hline Chydorus sphaericus & 1,4 & 1.14 & 0.347 & 5,20 & 18.14 & $<0.001$ & 5,20 & 0.69 & 0.563 \\
\hline Holopedium gibberum & 1,4 & 0.43 & 0.550 & 5,20 & 34.22 & $<0.001$ & 5,20 & 1.27 & 0.321 \\
\hline Sida crystallina & 1,4 & $<0.01$ & 0.952 & 5,20 & 44.24 & $<0.001$ & 5,20 & 1.03 & 0.412 \\
\hline Diacyclops thomasi & 1,4 & 0.01 & 0.930 & 5,20 & 26.19 & $<0.001$ & 5,20 & 0.49 & 0.629 \\
\hline Mesocyclops edax & 1,4 & 0.16 & 0.707 & 5,20 & 11.56 & $<0.001$ & 5,20 & 0.31 & 0.902 \\
\hline Tropocyclops extensus & 1,4 & 1.80 & 0.251 & 5,20 & 29.26 & $<0.001$ & 5,20 & 1.72 & 0.176 \\
\hline Zooplankton biomass & 1,4 & 7.79 & 0.049 & 5,20 & 10.50 & $<0.001$ & 5,20 & 1.61 & 0.203 \\
\hline
\end{tabular}

Notes: $P$ values reported for Time and Time $\times \mathrm{pH}$ Treatment interaction have been corrected for departure from sphericity using the Huynh-Feldt adjustment. For zooplankton population responses, bold $P$ values indicate $P<0.05$, while $P$ values in bold italics were significant at alpha $<0.05$ after Bonferroni correction for the number of species tested per lake.

the course of the experiment in Trout Lake and Little Rock-Reference, whereas community structure became more similar in control and acidified treatments in Little Rock-Treatment. At the end of the experiment, community similarity was lowest in Trout Lake (0.42), intermediate in Little Rock-Reference (0.72), and highest in Little Rock-Treatment (0.88). In Trout Lake, total zooplankton biomass was significantly reduced with acidification (Fig. 2, Table 2). In contrast, acidification had insignificant or weak effects on total zooplankton biomass in Little Rock-Reference and Little RockTreatment (Fig. 2, Table 2).

Differences among sites in community-level sensitivity to acidification were caused by variation in population-level responses. Overall, zooplankton population responses were strongest in Trout Lake and weakest in Little Rock-Treatment (Fig. 3, Table 2). Seventyone percent $(5 / 7)$ of dominant zooplankton species in Trout Lake exhibited significant ( $P<P_{\text {critical }}$ after Bonferroni correction for number of species tested) or marginally significant $(P<0.05)$ responses to acidification, compared to $50 \%(3 / 6)$ and $14 \%(1 / 7)$ in Little Rock-Reference and Little Rock-Treatment, respectively. We considered population responses to acidification to include significant main effects of treatment, as well as significant time by treatment interactions. Main effects of acid treatment test for differences in average densities, whereas the time by treatment in- teraction tests for differences in population trajectories through time (Gurevitch and Chester 1986, Potvin et al. 1990, von Ende 1993). In rare cases where a significant time by treatment interaction was found in association with a nonsignificant treatment effect, we concluded that the population had responded to acidification only when ANOVA conducted for each sample date separately indicated significant treatment differences.

In Trout Lake, nearly all dominant zooplankton species were affected adversely by acidification (Fig. 3, Table 2). Average densities of Daphnia mendotae and Tropocyclops extensus were significantly lower in the acidified treatment than in the control. In addition, acidification caused a marginally significant reduction in average density for Diacyclops thomasi (i.e., $P_{\mathrm{trt}}<0.05$ but $P_{\mathrm{trt}}>$ critical Bonferroni-corrected $P$-value). Bosmina longirostris, Daphnia mendotae, Holopedium gibberum, and Tropocyclops extensus followed significantly different population trajectories in control and acidified treatments, as indicated by significant time by treatment interactions for these species. Average densities of Holopedium gibberum differed significantly between control and acidified treatments during weeks 1-3 (week $1, F_{1,3}=45.69, P=0.007$; week $2, F_{1,3}=$ 45.25, $P=0.007$; week $\left.3, F_{1,3}=69.49, P=0.004\right)$. Average densities of Bosmina longirostris differed significantly between control and acidified treatments dur- 

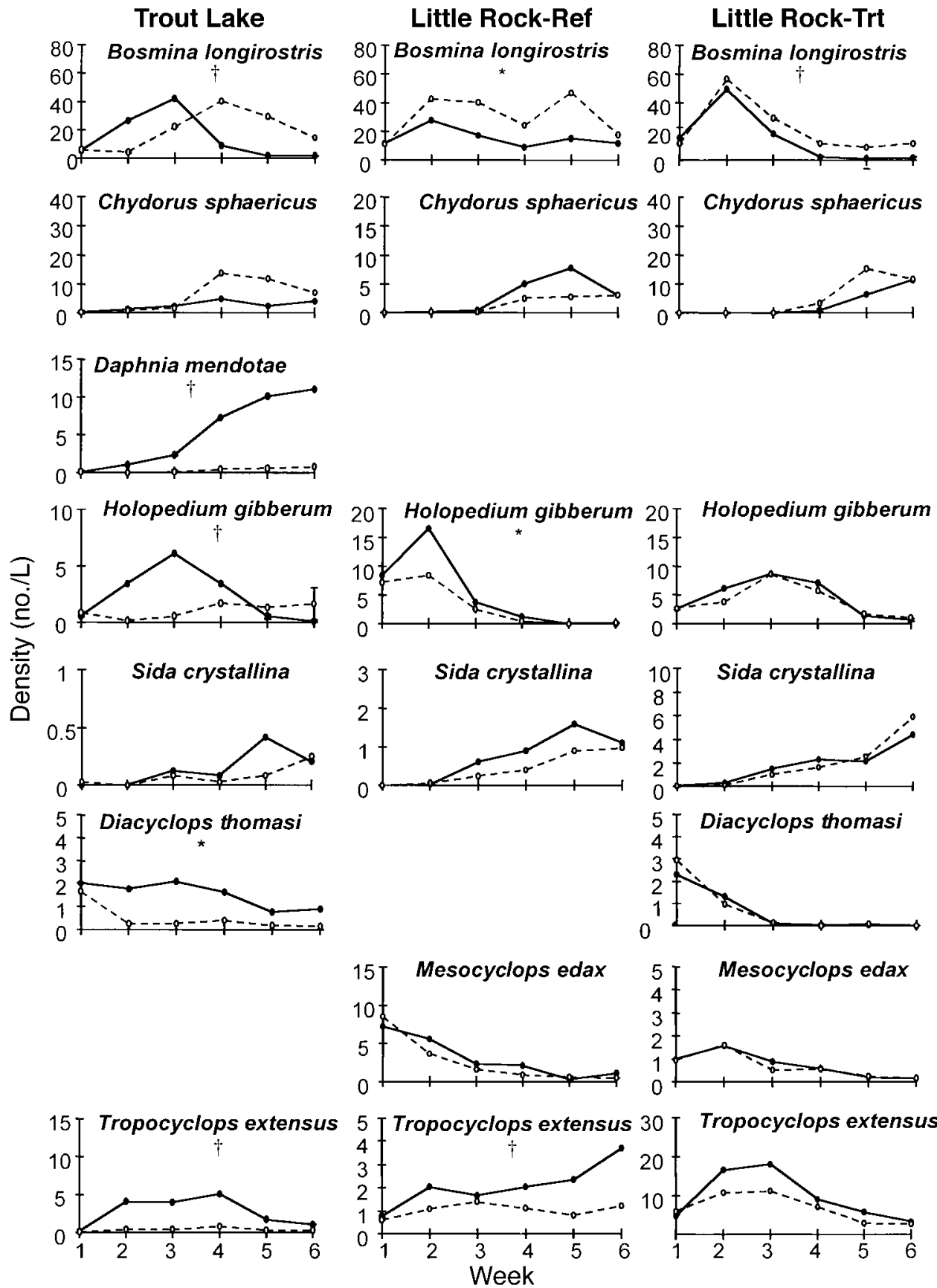

Fig. 3. Zooplankton population dynamics in the mesocosm experiment for Trout Lake, Little Rock-Reference, and Little Rock-Treatment. Means are plotted for control (solid circle) and acidified (open circle) treatments. Only dominant species ( $>5 \%$ by biomass or abundance in either treatment) are plotted for each site. In this figure, species are organized alphabetically within each major group (cladocerans followed by copepods). Asterisks below species names indicate significant responses to acidification as judged by a main effect of $\mathrm{pH}$ treatment and/or a time $\times \mathrm{pH}$ treatment interaction $(\dagger P<0.05$ after Bonferroni correction for the number of species tested per site; $* P<0.05)$. Detailed statistics are presented in Table 2.

ing weeks 2 and 5 (week $2, F_{1,3}=11.86, P=0.041$; week $\left.5, F_{1,3}=15.76, P=0.029\right)$.

In comparison to the dramatic population responses in Trout Lake, responses to acidification by Little RockReference zooplankton were relatively weak (Fig. 3, Table 2). Acidification resulted in a significant reduc- tion in average density for Tropocyclops extensus. In addition, marginally significant treatment effects were detected for Bosmina longirostris and Holopedium gibberum. Interestingly, average Bosmina longirostris densities were higher in the acidified treatment than in the control. Finally, Holopedium gibberum and Tro- 


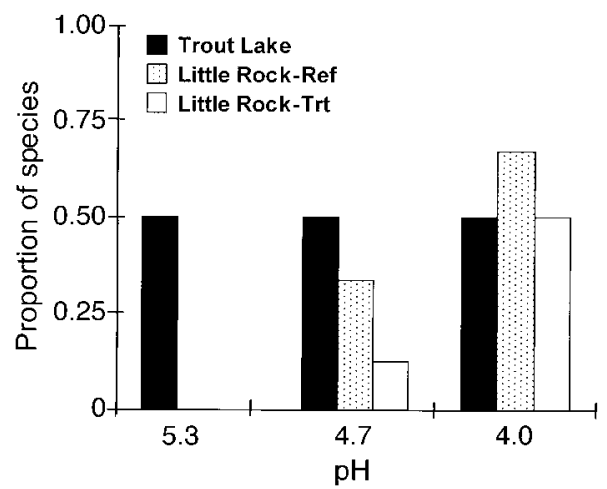

FIG. 4. Proportion of crustacean zooplankton species in the $\mathrm{pH}$ gradient experiment exhibiting significant decreases in density at reduced $\mathrm{pH}$ compared to the control for Trout Lake, Little Rock-Reference, and Little Rock-Treatment.

pocyclops extensus followed different trajectories in control and acidified treatments, as indicated by marginally significant or significant time by treatment interactions for these species.

In Little Rock-Treatment, zooplankton populations were highly resistant to acidification (Fig. 3, Table 2). In fact, only one species (Bosmina longirostris) responded significantly to acidification. Average Bosmina longirostris density was significantly higher in the acidified treatment $(21.6 \pm 0.9$ individuals/L $)$ than in the control $(14.7 \pm 2.4$ individuals/L). Although this effect was statistically significant, the magnitude of the effect was relatively small (Fig. 3).

Because zooplankton species composition in mesocosms was similar among study sites, we could com- pare population responses for the same species across sites. In several cases where a species occurred in more than one study site, significant or marginally significant responses to acidification were detected in Trout Lake and/or Little Rock-Reference, but not in Little RockTreatment (Fig. 3, Table 2; see Holopedium gibberum, Diacyclops thomasi, and Tropocyclops extensus).

\section{pH gradient experiment}

The $\mathrm{pH}$ gradient experiment indicated that population sensitivity to acidification varied among sites consistently with our expectations based on acidification history. In all cases, detrimental effects of acidification on population densities were detected at all $\mathrm{pH}$ levels below a critical threshold $\mathrm{pH}$. However, the threshold for population declines differed among study sites (Fig. 4, Table 3). At pH 5.3, 50\% (2/4) of species from Trout Lake were detrimentally affected whereas none of the species from Little Rock-Reference (0/6) or Little Rock-Treatment (0/8) responded significantly to acidification. At $\mathrm{pH} 4.7$ (the target acidification level in the mesocosm experiment), the ranking of responses paralleled the mesocosm experiment. That is, the Trout Lake assemblage was most sensitive and the Little Rock-Treatment assemblage was least sensitive. However, a large proportion of species responded in all sites when $\mathrm{pH}$ was reduced to 4.0 , a level more acidic than historical conditions in all sites.

When we restricted our analysis to those species occurring in at least two of the study sites, we found that populations from the site with the mildest previous exposure to acidification tended to exhibit the most sensitive response to experimental reduction in $\mathrm{pH}$

TABLE 3. One-way ANOVA for population responses to acidification in the $\mathrm{pH}$ gradient experiment.

\begin{tabular}{|c|c|c|c|c|c|c|c|}
\hline \multirow[b]{2}{*}{ Species } & \multirow[b]{2}{*}{ Lake } & \multicolumn{3}{|c|}{$\mathrm{pH}$} & \multicolumn{3}{|c|}{ Contrasts } \\
\hline & & $\mathrm{df}$ & $F$ & $P$ & 5.3 & 4.7 & 4.0 \\
\hline \multirow[t]{2}{*}{ Bosmina longirostris } & Trout & 3,6 & 1.00 & 0.455 & & & \\
\hline & Little Rock-Trt & 3,8 & 2.77 & 0.111 & & & \\
\hline Chydorus sphaericus & Trout & 3,6 & 1.85 & 0.239 & & & \\
\hline Daphnia catawba & Little Rock-Trt & 3,8 & 10.02 & 0.004 & & & * \\
\hline \multirow[t]{2}{*}{ Daphnia dubia } & Little Rock-Ref & 3,8 & 14.38 & 0.001 & & $*$ & * \\
\hline & Little Rock-Trt & 3,8 & 9.59 & 0.005 & & $*$ & $*$ \\
\hline Daphnia parvula & Little Rock-Trt & 3,8 & 3.57 & 0.067 & & & \\
\hline Diaphanosoma birgei & Little Rock-Ref & 3,8 & 3.31 & 0.078 & & & \\
\hline \multirow[t]{3}{*}{ Holopedium gibberum } & Trout & 3,6 & 5.47 & 0.037 & * & $*$ & $*$ \\
\hline & Little Rock-Ref & 3,8 & 4.67 & 0.036 & & & $\dagger$ \\
\hline & Little Rock-Trt & 3,8 & 2.07 & 0.183 & & & \\
\hline \multirow[t]{2}{*}{ Diacyclops thomasi } & Trout & 3,6 & 50.36 & $<0.001$ & * & * & * \\
\hline & Little Rock-Trt & 3,8 & 15.45 & 0.001 & & & * \\
\hline \multirow[t]{2}{*}{ Diaptomus minutus } & Little Rock-Ref & 3,8 & 60.73 & $<0.001$ & & $*$ & $*$ \\
\hline & Little Rock-Trt & 3,8 & 3.19 & 0.084 & & & \\
\hline \multirow[t]{2}{*}{ Mesocyclops edax } & Little Rock-Ref & 3,8 & 4.55 & 0.038 & & & * \\
\hline & Little Rock-Trt & 3,8 & 15.68 & 0.001 & & & * \\
\hline Tropocyclops extensus & Little Rock-Ref & 3,8 & 12.60 & 0.002 & & & * \\
\hline
\end{tabular}

Notes: For species where one-way ANOVA indicated a significant $\mathrm{pH}$ effect, we performed Dunnett's contrasts to test for significant decreases in population density in each acidified treatment compared to the control. Asterisks in the contrasts column indicate acidified treatments where population densities were significantly lower than ambient $($ alpha $<0.05)$.

$\dagger P=0.06$. 
Bosmina longirostris
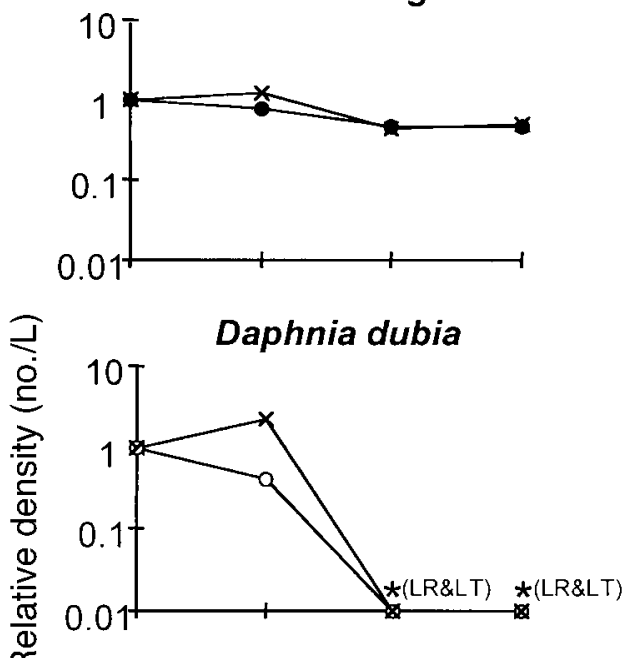

Holopedium gibberum

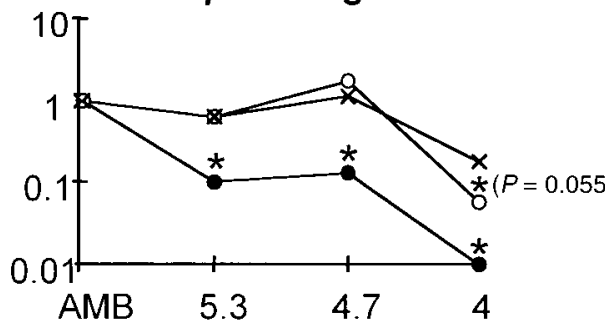

Diacyclops thomasi

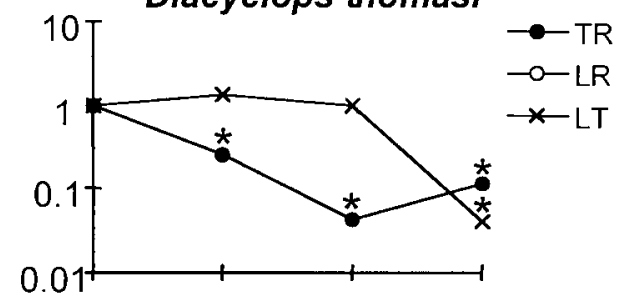

Diaptomus minutus
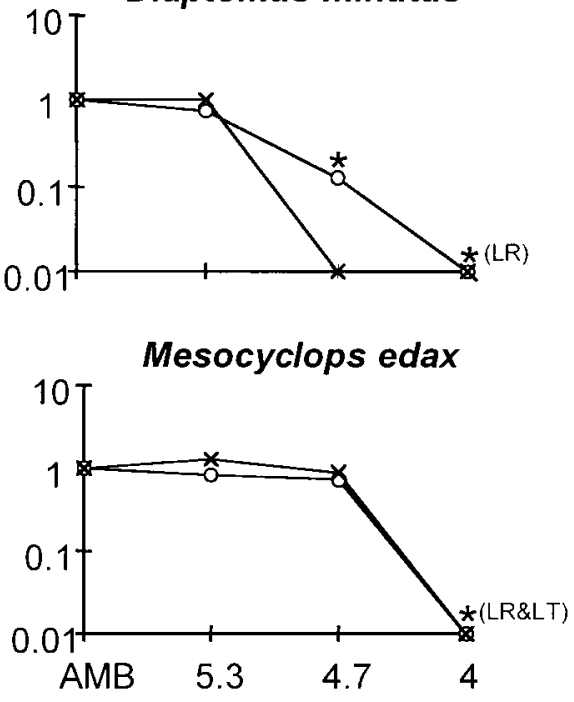

$\mathrm{pH}$

FIG. 5. Relative population densities of crustacean zooplankton at each $\mathrm{pH}$ level at the end of the $\mathrm{pH}$ gradient experiment. To facilitate comparisons among sites, we calculated relative densities (mean population density for each treatment was divided by mean population density in the control). Asterisks indicate acidified treatments where population densities were significantly lower than ambient $\mathrm{pH}$, i.e., where the relative density was significantly $<1$. Site codes: TR, Trout Lake; LR, Little Rock-Reference; LT, Little Rock-Treatment.

(Fig. 5, Table 3). For example, Diacyclops thomasi from Trout Lake was detrimentally affected in all acidified treatments, whereas Diacyclops thomasi from Little Rock-Treatment tolerated acidification at $\mathrm{pH} 5.3$ and 4.7 but declined at $\mathrm{pH}$ 4.0. In general, the threshold $\mathrm{pH}$ for population decreases occurred in the order Trout Lake $\geq$ Little Rock-Reference $\geq$ Little Rock-Treatment (Table 3). The only exceptions to this pattern involved two relatively acid-tolerant species (Bosmina longirostris and Mesocyclops edax), which did not respond differentially among sites and Daphnia dubia, which responded to acidification at $\mathrm{pH} 4.7$ in both Little RockReference and Little Rock-Treatment.

\section{Reciprocal transplant experiment}

The reciprocal transplant experiment indicated that intersite variation in zooplankton responses to acidification was primarily due to differences in acid sensitivity among zooplankton populations (Fig. 6). For three of the five species tested (Diacyclops thomasi, Tropocyclops extensus, and Diaptomus minutus), we detected a statistically significant zooplankton source by $\mathrm{pH}$ interaction indicating that zooplankton response to $\mathrm{pH}$ depended on the site from which they were collected (Table 4). In addition, the three-way interaction between zooplankton source, water source, and $\mathrm{pH}$ was significant for two species (Holopedium gibberum and Diaptomus minutus).

In general, zooplankton populations from Little Rock-Treatment exhibited the weakest response to experimental reduction in $\mathrm{pH}$, as in our other experiments. For example, Diacyclops thomasi from Trout Lake was detrimentally affected by acidification $\left(\mathrm{pH} F_{1,12}=\right.$ 89.67, $P<0.001$; Water Source $F_{2,12}=6.44, P=0.012$; $\mathrm{pH} \times$ Water Source $\left.F_{2,12}=5.12, P=0.025\right)$, whereas $\mathrm{pH}$ had no significant effect on Diacyclops thomasi from Little Rock-Treatment $\left(\mathrm{pH} F_{1,7}=0.52, P=0.493\right.$; Water Source $F_{2,7}=2.05, P=0.200 ; \mathrm{pH} \times$ Water Source $\left.F_{2,7}=0.89, P=0.454\right)$. Similarly, two-way ANOVA indicated Tropocyclops extensus populations from Trout Lake and Little Rock-Reference were adversely affected by acidification (Trout Lake, $\mathrm{pH} F_{1,12}$ $=8.46, P=0.013$; Water Source $F_{2,12}=0.55, P=$ $0.591 ; \mathrm{pH} \times$ Water Source $F_{2,12}=0.76, P=0.488$; 


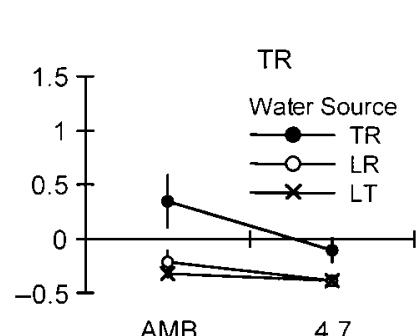

Holopedium gibberum
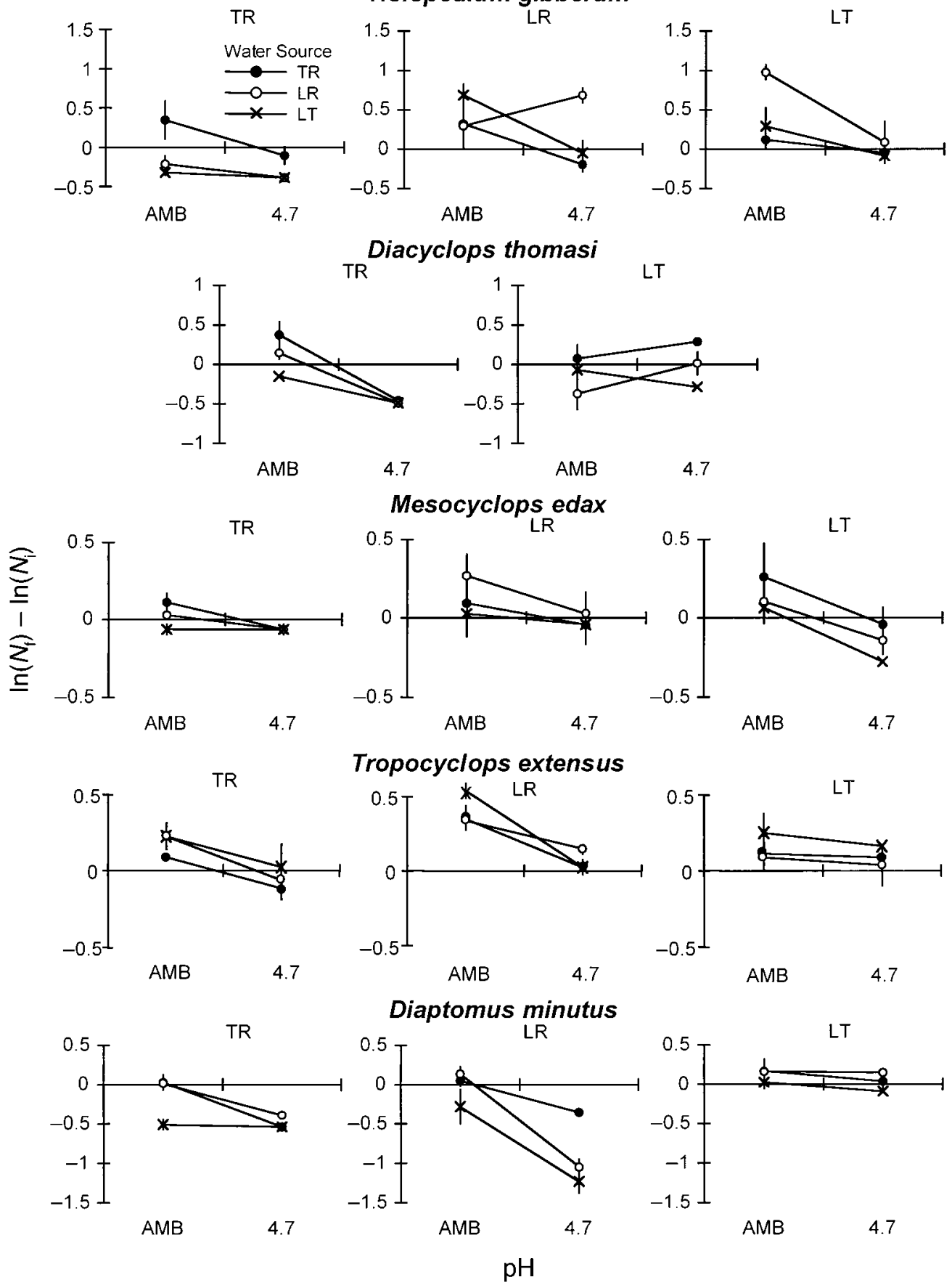

FIG. 6. Norms of reaction from the reciprocal transplant experiment. Change in population density during a 1-wk incubation [rho $=\ln \left(N_{\mathrm{f}}\right)-\ln \left(N_{\mathrm{i}}\right)$, where $N_{\mathrm{f}}$ and $N_{\mathrm{i}}$ are final and initial densitities] was plotted for each zooplankton source, water source, and $\mathrm{pH}$ treatment combination. Each panel represents a species collected from a particular site (i.e., zooplankton source). Site codes: TR, Trout Lake; LR, Little Rock-Reference; LT, Little Rock-Treatment. Treatment (pH) codes: AMB, ambient $\mathrm{pH} ; 4.7, \mathrm{pH}$ 4.7. Vertical bars indicate \pm 1 SE.

Little Rock-Reference, $\mathrm{pH} F_{1,10}=59.67, P<0.001$; Water Source $F_{2,10}=1.42, P=0.286 ; \mathrm{pH} \times$ Water Source $F_{2,10}=4.43, P=0.042$ ), whereas $\mathrm{pH}$ had no significant effect on Tropocyclops extensus from Little Rock-Treatment ( $\mathrm{pH} F_{1,7}=0.28, P=0.616$; Water
Source $F_{2,7}=0.72, P=0.520 ; \mathrm{pH} \times$ Water Source $\left.F_{2,7}=0.03, P=0.975\right)$. Finally, Diaptomus minutus from Trout Lake and Little Rock-Reference were detrimentally affected by acidification (Trout Lake, $\mathrm{pH}$ $F_{1,12}=88.76, P<0.001 ;$ Water Source $F_{2,12}=33.49$, 
TABLE 4. Three-way ANOVA for main effects of $\mathrm{pH}$, zooplankton source, and water source, as well as two- and threeway interactions between these factors in the reciprocal transplant experiment.

\begin{tabular}{|c|c|c|c|c|c|}
\hline Species & Sites & Effect & df & $F$ & $P$ \\
\hline Holopedium gibberum & TR, LR, LT & $\begin{array}{l}\mathrm{pH} \\
\text { Water Source } \\
\text { Zooplankton Source } \\
\text { Water Source by pH } \\
\text { Zooplankton Source by pH } \\
\text { Zooplankton Source by Water Source } \\
\text { Zooplankton Source by Water Source by pH }\end{array}$ & $\begin{array}{l}1,29 \\
2,29 \\
2,29 \\
2,29 \\
2,29 \\
4,29 \\
4,29\end{array}$ & $\begin{array}{r}17.12 \\
2.66 \\
14.98 \\
0.44 \\
0.80 \\
5.67 \\
4.38\end{array}$ & $\begin{array}{r}<\mathbf{0 . 0 0 1} \\
0.087 \\
<\mathbf{0 . 0 0 1} \\
0.646 \\
0.458 \\
\mathbf{0 . 0 0 2} \\
\mathbf{0 . 0 0 7}\end{array}$ \\
\hline Diaptomus minutus & TR, LR, LT & $\begin{array}{l}\mathrm{pH} \\
\text { Water Source } \\
\text { Zooplankton Source } \\
\text { Water Source by } \mathrm{pH} \\
\text { Zooplankton Source by } \mathrm{pH} \\
\text { Zooplankton Source by Water Source } \\
\text { Zooplankton Source by Water Source by pH }\end{array}$ & $\begin{array}{l}1,29 \\
2,29 \\
2,29 \\
2,29 \\
2,29 \\
4,29 \\
4,29\end{array}$ & $\begin{array}{r}103.83 \\
18.61 \\
40.95 \\
1.53 \\
27.55 \\
3.21 \\
7.94\end{array}$ & $\begin{array}{r}<\mathbf{0 . 0 0 1} \\
<\mathbf{0 . 0 0 1} \\
<\mathbf{0 . 0 0 1} \\
0.234 \\
<\mathbf{0 . 0 0 1} \\
\mathbf{0 . 0 2 6} \\
<\mathbf{0 . 0 0 1}\end{array}$ \\
\hline Diacyclops thomasi & TR, LT & $\begin{array}{l}\mathrm{pH} \\
\text { Water Source } \\
\text { Zooplankton Source } \\
\text { Water Source by } \mathrm{pH} \\
\text { Zooplankton Source by } \mathrm{pH} \\
\text { Zooplankton Source by Water Source } \\
\text { Zooplankton Source by Water Source by pH }\end{array}$ & $\begin{array}{l}1,19 \\
2,19 \\
1,19 \\
2,19 \\
1,19 \\
2,19 \\
2,19\end{array}$ & $\begin{array}{r}8.63 \\
6.04 \\
2.26 \\
0.52 \\
20.69 \\
0.77 \\
3.34\end{array}$ & $\begin{array}{r}\mathbf{0 . 0 0 8} \\
\mathbf{0 . 0 0 9} \\
0.149 \\
0.602 \\
<\mathbf{0 . 0 0 1} \\
0.478 \\
0.057\end{array}$ \\
\hline Mesocyclops edax & TR, LR, LT & $\begin{array}{l}\mathrm{pH} \\
\text { Water Source } \\
\text { Zooplankton Source } \\
\text { Water Source by pH } \\
\text { Zooplankton Source by } \mathrm{pH} \\
\text { Zooplankton Source by Water Source } \\
\text { Zooplankton Source by Water Source by pH }\end{array}$ & $\begin{array}{l}1,29 \\
2,29 \\
2,29 \\
2,29 \\
2,29 \\
4,29 \\
4,29\end{array}$ & $\begin{array}{r}10.71 \\
1.63 \\
0.79 \\
0.15 \\
1.19 \\
0.69 \\
0.23\end{array}$ & $\begin{array}{l}\mathbf{0 . 0 0 3} \\
0.214 \\
0.463 \\
0.861 \\
0.319 \\
0.604 \\
0.922\end{array}$ \\
\hline Tropocyclops extensus & TR, LR, LT & $\begin{array}{l}\mathrm{pH} \\
\text { Water Source } \\
\text { Zooplankton Source } \\
\text { Water Source by } \mathrm{pH} \\
\text { Zooplankton Source by } \mathrm{pH} \\
\text { Zooplankton Source by Water Source } \\
\text { Zooplankton Source by Water Source by pH }\end{array}$ & $\begin{array}{l}1,29 \\
2,29 \\
2,29 \\
2,29 \\
2,29 \\
4,29 \\
4,29\end{array}$ & $\begin{array}{r}23.80 \\
2.09 \\
6.23 \\
0.78 \\
4.06 \\
0.24 \\
0.94\end{array}$ & $\begin{array}{r}<\mathbf{0 . 0 0 1} \\
0.142 \\
\mathbf{0 . 0 0 6} \\
0.468 \\
\mathbf{0 . 0 2 8} \\
0.914 \\
0.456\end{array}$ \\
\hline
\end{tabular}

Notes: The response variable was change in population density during a 1 -wk incubation $\left[\right.$ rho $=\ln \left(N_{\mathrm{f}}\right)-\ln \left(N_{\mathrm{i}}\right)$, where $N_{\mathrm{f}}$ and $N_{\mathrm{i}}$ are final and initial densities]. Sites codes: TR, Trout Lake; LR, Little Rock-Reference; LT, Little Rock-Treatment. Bold indicates $P<0.05$

$P=0.001 ; \mathrm{pH} \times$ Water Source $F_{2,12}=19.28, P<$ 0.001; Little Rock-Reference, $\mathrm{pH} F_{1,10}=83.90, P<$ 0.001 ; Water Source $F_{2,10}=9.59, P=0.005 ; \mathrm{pH} \times$ Water Source $F_{2,10}=6.50, P=0.016$ ); however, $\mathrm{pH}$ had no significant effect on Diaptomus minutus from Little Rock-Treatment $\left(\mathrm{pH} F_{1,7}=1.37, P=0.280\right.$; Water Source $F_{2,7}=1.60, P=0.268 ; \mathrm{pH} \times$ Water Source $\left.F_{2,7}=0.38, P=0.695\right)$.

Differences in population sensitivity among sites were not observed for Mesocyclops edax or Holopedium gibberum. For Mesocyclops edax, responses to acidification did not differ among sites, as indicated by the lack of a significant zooplankton source by $\mathrm{pH}$ interaction or a three-way interaction in Table 4. In contrast, Holopedium gibberum was affected by acidification in all three sites (Trout Lake, $\mathrm{pH} F_{1,12}=6.02$, $P=0.030$; Water Source $F_{2,12}=10.07, P=0.003 ; \mathrm{pH}$ $\times$ Water Source $F_{2,12}=1.53, P=0.255$; Little RockReference, $\mathrm{pH} F_{1,10}=3.44, P=0.093$; Water Source $F_{2,10}=2.38, P=0.142 ; \mathrm{pH} \times$ Water Source $F_{2,10}=$ $4.90, P=0.033$; Little Rock-Treatment, $\mathrm{pH} F_{1,7}=7.40$,
$P=0.030 ;$ Water Source $F_{2,7}=3.37, P=0.094 ; \mathrm{pH}$ $\times$ Water Source $\left.F_{2,7}=1.68, P=0.254\right)$.

In contrast to the strong effects of zooplankton source, effects of water source on zooplankton responses to acidification were relatively weak. We failed to detect a significant water source by $\mathrm{pH}$ interaction for any of the species tested, indicating that water source alone was not driving zooplankton responses to $\mathrm{pH}$. However, for Holopedium gibberum and Diaptomus minutus, the effects of water source on responses to acidification were detected as complex three-way interactions, indicating that both zooplankton population differences and environment factors affected responses to acid for these species. In several cases (e.g., Holopedium gibberum, Diacyclops thomasi, and Mesocyclops edax), we noted that zooplankton collected from Trout Lake achieved higher rho values at ambient $\mathrm{pH}$ in Trout Lake water than in water from Little Rock Lake. This result may indicate that Trout Lake zooplankton are intolerant to the $\mathrm{pH}$ conditions in ambient Little Rock Lake water (pH 5.8-6.1). 
In sum, the reciprocal transplant experiment indicated that differential responses of populations of the same zooplankton species to acidification were not caused simply by differences in water chemistry, algal resources, or other site-specific environmental variables. Instead, variation in population responses to acidification was caused primarily by differences in acid sensitivity among the zooplankton populations.

\section{Discussion}

Our study highlights the effects of ecological history on community-level responses to environmental change. In comparative experiments conducted in three study sites with different acidification histories, zooplankton exhibited widely divergent population- and community-level responses to acidification. Zooplankton populations responded most sensitively to acidification in Trout Lake, where high acid neutralizing capacity had buffered changes in $\mathrm{pH}$ historically. For most species, population densities were severely reduced in the acidified treatment compared to the control. Acidification was a novel perturbation for the Trout Lake community because $\mathrm{pH}$ manipulations changed the system outside of the range of historical variation. The results from Trout Lake indicate that ecological systems are likely to be highly sensitive to perturbations for which they have no history (e.g., novel temperature regimes caused by climate change, new chemical stressors associated with human activities, and exotic species).

In contrast to the novelty of acidification for the Trout Lake community, zooplankton in Little Rock Lake had varying degrees of prior exposure to acidification. In Little Rock-Reference, $\mathrm{pH}$ is routinely as low as 5.4 during the period just after ice-off due to natural processes associated with $\mathrm{CO}_{2}$ buildup under the ice (Kratz et al. 1987). In this site, zooplankton responses were more moderate than responses in Trout Lake. In contrast, Little Rock-Treatment had a history of sustained acidification due to experimental acidification during the 1980s. We found that Little RockTreatment zooplankton were highly resistant in our acidification experiments.

As a result of variation in population-level responses to acidification, sites also differed in the sensitivity of community-level variables to acidification. In the mesocosm experiment, differences in community composition between acidified and control treatments were most dramatic in the highly buffered site (Trout Lake), intermediate in the site that experiences seasonal fluctuations in $\mathrm{pH}$ (Little Rock-Reference), and weakest in the experimentally acidified site (Little Rock-Treatment). Furthermore, total zooplankton biomass was significantly reduced with acidification in Trout Lake due to declines of many acid-sensitive populations. In contrast, effects of acidification on zooplankton biomass in Little Rock-Treatment were weak because zooplankton populations were highly resistant to acidifi- cation. In Little Rock-Reference, zooplankton biomass was not significantly affected by acidification because decreases in the few sensitive species were matched by compensatory increases in other species (e.g., decreases in Holopedium gibberum and Tropocyclops extensus were coupled with an increase in Bosmina longirostris).

Community-level responses to acidification arise from direct effects of acidification on survival and/or reproduction, as well as indirect pathways operating through species interactions (Webster et al. 1992, Fischer 1997, Fischer and Frost 1997, Klug et al. 2000). Previous laboratory bioassays indicate that Holopedium gibberum is an acid-sensitive species (Havas and Likens 1985). The dramatic reduction in Holopedium abundance with acidification in Trout Lake mesocosms can, therefore, be interpreted as a direct response to acidification. In contrast, Bosmina longirostris is acid tolerant and often dominates the zooplankton community in acidified lakes (Yan and Strus 1980). In our experiment, Bosmina longirostris increased with acidification. This response was likely an indirect effect caused by competitive release following changes in the abundance of other species. Clearly, the magnitude and number of direct responses to acidification can play critical roles in determining the extent of indirect effects (Abrams et al. 1996), and both direct and indirect effects affect community-level responses to acidification.

In part, the contrasting community-level responses to acidification in Trout Lake, Little Rock-Reference, and Little Rock-Treatment were due to differences in the species composition of the three communities. For example, the acid-sensitive cladoceran Daphnia mendotae was present in Trout Lake but does not occur in Little Rock Lake. We observed a dramatic reduction in Daphnia mendotae abundance with acidification in Trout Lake mesocosms. Previous laboratory bioassays and lake surveys indicate that Daphnia mendotae is an acid-sensitive species that does not persist in lakes with $\mathrm{pH}<6$ (Keller et al. 1990). Therefore, the dramatic response of Daphnia mendotae in Trout Lake and the absence of this species from Little Rock Lake illustrates how species composition can play a role in intersite variation in community responses to acidification. Thus, changes in zooplankton species composition during past acidification events can decrease sensitivity to subsequent acidification in the same way that changes in species composition reduce the effects of repeated winterkills in lakes (Tonn and Magnuson 1982) and repeated fires in forests (Muir 1993, Turner et al. 1997). Species composition in Little Rock-Reference and Little Rock-Treatment was virtually identical (except for Diacyclops thomasi, which occurred only in Little Rock-Treatment). Therefore, differential responses to acidification in these two sites could not be explained simply by the presence/absence of particular species.

We found evidence that variation in community responses to acidification can also arise due to popula- 
tion-level differences in acid tolerance. In the six week long mesocosm experiment, those species that occurred across study sites were relatively less sensitive to experimental $\mathrm{pH}$ manipulations in Little Rock-Treatment than in Trout Lake and/or Little Rock-Reference. This pattern was also evident in the $\mathrm{pH}$ gradient experiment where the critical threshold for detrimental effects of acidification occurred at a lower $\mathrm{pH}$ level in Little Rock-Treatment than in the other sites. Furthermore, the reciprocal transplant experiment indicated that this pattern was driven primarily by population differences in acid tolerance, rather than other factors (e.g., water chemistry or food resources) that might differ among sites.

Our results indicate that changes in acid sensitivity of zooplankton can occur rapidly. We were particularly interested to find that the sensitivity of Tropocyclops extensus to acidification differed between Little RockReference and Little Rock-Treatment (Fig. 6). Presumably, these two populations existed as a single wellmixed population before the lake basins were separated in 1983. Tropocyclops extensus became the dominant copepod species in Little Rock-Treatment during the most acidic phase of the whole-lake acidification (Frost et al. 1995). Our results suggest that this dramatic increase in Tropocyclops extensus may be attributable to increases in acid tolerance by Tropocyclops in Little Rock-Treatment.

Our results support the hypothesis that zooplankton population differences in acid tolerance can arise due to evolutionary processes. Zooplankton are likely candidates for rapid evolutionary responses to environmental conditions. Other studies have reported differences in life history characteristics for zooplankton populations from different environments, some of which are heritable (Tessier 1986, Wyngaard 1986a, $b$, Tessier and Consolatti 1989, Hairston and Dillon 1990, Ellner et al. 1999). Furthermore, a recent study by Hairston et al. (1999) has documented rapid evolution of tolerance of toxic bluegreen algae by Daphnia during the eutrophication of Lake Constance. Therefore, we believe that the relatively short generation times of crustacean zooplankton (weeks to months) and strong selective pressures exerted by six years of experimentally reduced $\mathrm{pH}$ in Little Rock-Treatment could have combined to cause rapid evolution of acid tolerance in some zooplankton species. Detailed genetic studies comparing populations would strengthen our interpretations, but these studies are beyond the scope of this study.

It is noteworthy that we detected population differences in acid tolerance in the $\mathrm{pH}$ gradient and reciprocal transplant experiments, which were conducted during the summer of 1997. At this time, abiotic and biotic conditions were virtually identical in Little Rock-Reference and Little Rock-Treatment (Frost et al. 1998; T. M. Frost, unpublished data). Furthermore, pH conditions in Little Rock-Treatment had recovered sev- eral years earlier (see Methods: Study sites description). Therefore, it seems unlikely that our results reflect phenotypic plasticity, maternal effects, or effects of individual condition on acid tolerance because many generations of zooplankton had occurred in Little RockTreatment under the relatively benign $\mathrm{pH}$ conditions of 1994-1997. However, without additional experiments in which zooplankton are raised for several generations in a common environment, we can not rule out the possibility that maternal effects can influence acid tolerance.

Similarly, without additional experiments conducted repeatedly through time, we have no way to assess whether increased acid tolerance in Little Rock-Treatment populations will persist through time. If tolerance imposes costs in performance of other activities, we expect acid tolerance to be lost under recovered $\mathrm{pH}$ conditions. In that case, enhanced resistance to acidification would be a transitory effect in Little RockTreatment. However, we found enhanced resistance in 1997, which was several years into recovery, suggesting that the costs of acid tolerance may be low and that the return of Little Rock-Treatment zooplankton to preacidification levels of acid tolerance may not be rapid. It is also important to note that the Little Rock acidification is an example of a perturbation where selection pressure was imposed and then relaxed. In other cases where perturbations are maintained or repeated through time, we would expect these more constant selection pressures to maintain stress-tolerant populations.

Previous studies on the specific physiological mechanisms controlling acid tolerance have implicated neuromuscular dysfunction associated with hydrogen and aluminum binding at ion exchange sites as the cause of high mortality of zooplankton in acidic waters (Havas and Likens 1985, Havens 1990). It is unlikely that aluminum toxicity played a critical role in our experiments. When lakes are acidified as a result of acid rain, aluminum ion concentrations can reach high levels because aluminum is leached from watershed soils and sediments (Cronan and Schofield 1979). However, our $\mathrm{pH}$ manipulations were in bags and small containers and, therefore, independent of the watershed soils and sediments. Similarly, aluminum levels were low during the whole lake acidification of Little Rock Lake because acid was added directly to the lake rather than the watershed. In fact, aluminum concentrations increased only moderately from initial concentrations of $<10 \mu \mathrm{g} / \mathrm{L}$ to an average of $38 \mu \mathrm{g} / \mathrm{L}$ at ph 4.7 (Brezonik et al. 1993). Aluminum concentrations of this level are characteristic of unacidified lakes and are not toxic to zooplankton (Havas and Likens 1985). Typically, aluminum becomes toxic to zooplankton at concentrations of hundreds or thousands of micrograms per liter (Havas and Likens 1985, Havens 1990).

To our knowledge, only one previous study has reported laboratory bioassays showing interpopulation variation in acid tolerance by zooplankton. Price and 
Swift (1985) used laboratory bioassays to demonstrate that Mesocyclops edax from an acidic pond were more acid tolerant than Mesocyclops edax collected from a more neutral pond. Our findings and their results suggest that variation in acid sensitivity among populations of the same species can be substantial. Nonetheless, it is common practice to infer the acid sensitivity of a species based on an assay of a single population (see review by Locke 1991). Gonzalez and Frost (1994) have cautioned against the use of laboratory bioassays to predict population responses to acidification at the whole-lake scale. Clearly, variation in population sensitivity to acidification may also contribute to a substantial difference between laboratory bioassays and population dynamics in the field.

Inter-site differences in the extent and nature of community-level responses to perturbation such as we have documented here may have important implications for predicting the ecosystem-level responses to stress. Previous studies have argued that sensitivity of ecosystem processes to perturbation decreases with increasing species diversity (Walker 1992, 1995, Tilman 1996). In these studies, variation in community responses to perturbation is caused by compensatory dynamics between perturbation-sensitive and perturbation-tolerant taxa. Species-rich communities may be more likely to contain perturbation-tolerant species, which can increase to compensate for the loss of perturbation-sensitive species.

Our study highlights another mechanism that can generate variation in ecosystem responses to perturbation. We found that historical conditions can lead to changes in perturbation tolerance of populations. Resistance and/or resilience of ecosystem processes to perturbation is likely to be greater in communities containing perturbation-tolerant populations than in communities dominated by sensitive populations. Furthermore, our results suggest that the effects of history on ecosystem responses to perturbation can operate independently of species richness. In our mesocosm experiment, the sensitivity of total zooplankton biomass (an aggregate measure often used to infer changes in ecosystem function) to acidification varied substantially among sites that contained a similar number of crustacean zooplankton species (range $=6-7$ dominant species).

Overall, our findings demonstrate that ecological history cannot be ignored when attempting to predict ecological responses to environmental perturbations. Ecosystems may respond sensitively to environmental changes that fall outside of the range of historical conditions. Thus, disruption of ecosystem functions and services is likely following natural and anthropogenic disturbances that create extreme conditions. Our results also suggest that, under some circumstances, rapid evolution may buffer community responses against subsequent perturbations of the same type. The extent of rapid evolution and buffering of community responses to future perturbations is likely to be system specific. Therefore, our findings reinforce previous calls for research integrating ecology and evolution (Antonovics and Levin 1980, Parsons 1989, Holt 1995, McPeak and Miller 1996, Thompson 1998), two disciplines that have traditionally been viewed as operating on different time scales. Such research may provide the basis for a predictive understanding of the ecological responses to a rapidly changing environment.

\section{ACKNOWLEDGMENTS}

We are grateful to S. E. Arnott, A. J. Bohonak, S. R. Carpenter, S. I. Dodson, M. K. Clayton, N. G. Hairston, Jr., C. L. Holtmeier, J. G. Kingsolver, D. B. Lewis, J. J. Magnuson, M. H. Olson, D. E. Schindler, V. H. Smith, and four anonymous reviewers for helpful comments and constructive criticism. K. Beelick, A. Colby, T. Meinke, P. Montz, and M. H. Olson provided technical assistance. Funding in support of this research was provided by the National Science Foundation (NSF) through grants to T. M. Frost, A. R. Ives, and the Center for Limnology. Support was also provided by fellowships to J. M. Fischer (NSF Graduate Fellowship, Environmental Protection Agency STAR Graduate Fellowship, and NSF Postdoctoral Fellowship), by an Anna Grant Birge grant to J. L. Klug, and by the Center for Limnology-Trout Lake Station.

\section{Literature Cited}

Abrams, P. A., B. A. Menge, G. G. Mittelbach, D. A. Spiller, and P. Yodzis. 1996. The role of indirect effects in food webs. Pages 371-395 in G. A. Polis and K. O. Winemiller, editors. Food webs: integration of patterns and dynamics. Chapman \& Hall, New York, New York, USA.

Antonovics, J., and D. A. Levin. 1980. The ecological and genetic consequences of density-dependent regulation in plants. Annual Review of Ecology and Systematics 11:411452.

Bishop, J. A., and L. M. Cook. 1981. Genetic consequences of man made changes. Academic Press, New York, New York, USA.

Brezonik, P. L., L. A. Baker, J. R. Eaton, T. M. Frost, J. J. Magnuson, J. A. Perry, W. J. Rose, B. K. Shepard, W. A. Watras, and K. E. Webster. 1986. Experimental acidification of Little Rock Lake, Wisconsin. Water, Air and Soil Pollution 31:115-121.

Brezonik, P. L., et al. 1993. Experimental acidification of Little Rock Lake, Wisconsin: chemical and biological changes over the $\mathrm{pH}$ range 6.1 to 4.7. Canadian Journal of Fisheries and Aquatic Sciences 50:1101-1121.

Carriere, Y., D. A. Roff, and J.-P. Deland. 1995. The joint evolution of diapause and insecticide resistance: a test of an optimality model. Ecology 76:1497-1505.

Christy, E. J., and R. R. Sharitz. 1980. Characteristics of three populations of a swamp annual under different temperature regimes. Ecology 61:454-460.

Cronan, C. S., and C. L. Schofield. 1979. Aluminum leaching response to acid precipitation: effects on high-elevation watersheds in the northeast. Science 204:304-306.

Death, R. G. 1996. The effect of patch disturbance on stream invertebrate community structure: the influence of disturbance history. Oecologia 108:567-576.

Ellner, S. P., N. G. Hairston, Jr., C. M. Kearns, and D. Babai. 1999. The roles of fluctuating selection and long-term diapause in microevolution of diapause timing in a freshwater copepod. Evolution 53:111-122.

Fischer, J. M. 1997. Zooplankton community responses to acidification: the role of rapid evolution and compensatory dynamics. Dissertation, University of Wisconsin, Madison, Wisconsin, USA. 
Fischer, J. M., and T. M. Frost. 1997. Indirect effects of lake acidification on Chaoborus population dynamics: the role of food limitation and predation. Canadian Journal of Fisheries and Aquatic Sciences 54:637-646.

Foster, D. R. 1988. Disturbance history, community organization, and vegetation dynamics of the old-growth Pisgah forest, south-western New Hampshire, U.S.A. Journal of Ecology 76:105-134.

Frost, T. M., S. R. Carpenter, A. R. Ives, and T. K. Kratz. 1995. Species compensation and complementarity in ecosystem function. Pages 224-239 in C. G. Jones and J. H. Lawton, editors. Linking species and ecosystems. Chapman \& Hall, New York, New York, USA.

Frost, T. M., and P. M. Montz. 1988. Early zooplankton response to experimental acidification of Little Rock Lake, Wisconsin, USA. Verhandlungen-Internationale Vereinigung fur Theoretische und Angewandte Limnologie 23: $2279-2285$.

Frost, T. M., P. M. Montz, and T. K. Kratz. 1998. Zooplankton community responses during recovery from acidification: limited persistence by acid-favored species in Little Rock Lake, Wisconsin. Restoration Ecology 6:336-342.

Gonzalez, M. J., and T. M. Frost. 1994. Comparisons of laboratory bioassays and a whole-lake experiment: rotifer responses to experimental acidification. Ecological Applications 4:69-80.

Gurevitch, J., and S. T. Chester, Jr. 1986. Analysis of repeated measures experiments. Ecology 67:251-255.

Hairston, N. G., Jr., and T. A. Dillon. 1990. Fluctuating selection and response in a population of freshwater copepods. Evolution 44:1796-1805.

Hairston, N. G., Jr., W. Lampert, C. E. Caceres, C. L. Holtmeier, L. J. Weider, U. Gaedke, J. M. Fischer, J. A. Fox, and D. M. Post. 1999. Rapid evolution revealed by dormant eggs. Nature 401:446.

Havas, M., and G. E. Likens. 1985. Toxicity of aluminum and hydrogen ions to Daphnia catawba. Holopedium gibberum, Chaoborus punctipennis, and Chironomus anthrocinus from Mirror Lake, New Hampshire. Canadian Journal of Zoology 63:1114-1119.

Havens, K. E. 1990. Aluminum binding to ion-exchange sites in acid-sensitive versus acid-tolerant cladocerans. Environmental Pollution 64:133-141.

Holt, R. D. 1995. Linking species and ecosystems: where's Darwin? Pages 273-279 in C. G. Jones and J. H. Lawton, editors. Linking species and ecosystems. Chapman \& Hall, New York, New York, USA.

Hughes, T. P. 1989. Community structure and diversity of coral reefs: the role of history. Ecology 70:275-279.

Jaramillo, V. J. 1988. Grazing history, defoliation, and competition: effects on shortgrass production and nitrogen accumulation. Ecology 69:1599-1608.

Keller, W., N. D. Yan, K. E. Holtze, and J. R. Pitblado. 1990. Inferred effects of lake acidification on Daphnia galeata mendotae. Environmental Science and Technology 24: $1259-1261$.

Klerks, P. L., and J. S. Levinton. 1989. Rapid evolution of metal resistance in a benthic oligochaete inhabiting a metalpolluted site. Biological Bulletin 176:135-141.

Klug, J. L., J. M. Fischer, A. R. Ives, and B. Dennis. 2000. Compensatory dynamics in planktonic community responses to $\mathrm{pH}$ perturbations. Ecology 81:387-398.

Kratz, T. K., R. B. Cook, C. J. Bowser, and P. L. Brezonik. 1987. Winter and spring $\mathrm{pH}$ depressions in northern Wisconsin lakes caused by increases in $\mathrm{pCO}_{2}$. Canadian Journal of Fisheries and Aquatic Sciences 44:1082-1088.

Locke, A. 1991. Zooplankton responses to acidification: a review of laboratory bioassays. Water, Air and Soil Pollution 60:135-148.

Locke, A., and W. G. Sprules. 1993. Effects of acidification on zooplankton population and community dynamics. Canadian Journal of Fisheries and Aquatic Sciences 50:12381247.

McCauley, E. 1984. The estimation of the abundance and biomass of zooplankton in samples. Pages 228-265 in J. A. Downing and F. H. Rigler, editors. A manual on methods for the assessment of secondary production in fresh waters. Blackwell Scientific, Oxford, UK.

McPeek, M. A., and T. E. Miller. 1996. Evolutionary biology and community ecology. Ecology 77:1319-1320.

Menge, B. A., E. L. Berlow, C. A. Blanchette, S. A. Navarrete, and S. B. Yamada. 1994. The keystone species concept: variation in interaction strength in a rocky intertidal habitat. Ecological Monographs 64:249-286.

Morris, D. P., H. Zagarese, C. E. Williamson, E. G. Balseiro, B. R. Hargraves, B. Modenuti, R. E. Moeller, and C. Queimalinos. 1995. The attenuation of solar radiation in lakes and the role of dissolved organic carbon. Limnology and Oceanography 40:1381-1391.

Mueller-Dombois, D., and H. Ellenberg. 1974. Aims and methods of vegetation ecology. John Wiley \& Sons, New York, New York, USA

Muir, P. S. 1993. Disturbance effects on the structure and tree species composition of Pinus contorta forests in western Montana. Canadian Journal of Forest Research 23 $1617-1625$.

Parsons, P. A. 1989. Environmental stresses and conservation of natural populations. Annual Review of Ecology and Systematics 20:29-49.

Peters, R. H., and J. A. Downing. 1984. Empirical analysis of zooplankton filtering and feeding rates. Limnology and Oceanography 29:763-784.

Peterson, C. H., and R. Black. 1988. Density-dependent mortality caused by physical stress interacting with biotic history. American Naturalist 131:257-270.

Potvin, C., M. J. Lechowicz, and S. Tardif. 1990. The statistical analysis of ecophysiological response curves obtained from experiments involving repeated measures. Ecology 71:1389-1400.

Price, E. E., and M. C. Swift. 1985. Inter- and intra-specific variability in the response of zooplankton to acid stress. Canadian Journal of Fisheries and Aquatic Sciences 42: 1749-1754.

Price, T. D., P. R. Grant, H. L. Gibbs, and P. T. Boag. 1984. Recurrent patterns of natural selection in a population of Darwin's finches. Nature 309:787-789.

Reznick, D., and J. Travis. 1996. The empirical study of adaptation in natural populations. Pages 243-289 in M. R. Rose and G. V. Lauder, editors. Adaptation. Academic Press, San Diego, California, USA.

Reznick, D. N., F. H. Shaw, F. H. Rodd, and R. G. Shaw. 1997. Evaluation of the rate of evolution in natural populations of guppies (Poecilia retulata). Science 275:19341937.

Sampson, C. J. 1992. Chemical responses in experimentally acidified Little Rock Lake, Wisconsin. Dissertation. University of Minnesota, Minneapolis, Minnesota, USA.

Sampson, C. J., P. L. Brezonik, T. M. Frost, K. E. Webster, and T. D. Simonson. 1995. Experimental acidification of Little Rock Lake, Wisconsin: the first four years of chemical and biological recovery. Water, Air, and Soil Pollution 85: $1713-1719$

SAS. 1990. SAS/STAT User's guide, version 6. Fourth edition. SAS Institute, Cary, North Carolina, USA.

Schindler, D. W., T. M. Frost, K. H. Mills, P. S. S. Chang, I. J. Davies, L. Findlay, D. F. Malley, J. A. Shearer, M. A Turner, P. J. Garrison, C. J. Watras, K. Webster, J. M. Gumm, P. L. Brezonik, and W. A. Swenson. 1991. Comparisons between experimentally- and atmospherically- 
acidified lakes during stress and recovery. Proceedings of the Royal Society of Edinburgh 97:193-226.

Schoener, T. W. 1970. Nonsynchronous spatial overlap of lizards in patchy habitats. Ecology 51:408-417.

Smith, M. H., M. W. Smith, S. L. Scott, E. H. Liu, and J. C. Jones. 1983. Rapid evolution in a post-thermal environment. Copeia 1:193-197.

Tessier, A. J. 1986. Life history and body size evolution in Holopedium gibberum Zaddach (Crustacea, Cladocera). Freshwater Biology 16:279-286.

Tessier, A. J., and N. L. Consolatti. 1989. Variation in offspring size in Daphnia and consequences for individual fitness. Oikos 56:269-276.

Thompson, J. N. Rapid evolution as an ecological process. Trends in Ecology and Evolution 13:329-332.

Tilman, D. 1996. Biodiversity: population versus ecosystem stability. Ecology 77:350-363.

Tonn, W. M., and J. J. Magnuson. 1982. Patterns in the species composition and richness of fish assemblages in northern Wisconsin lakes. Ecology 63:1149-1166.

Turner, M. G., W. H. Romme, R. H. Gardner, and W. H. Hargrave. 1997. Effects of fire size and pattern on early succession in Yellowstone National Park. Ecological Monographs 67:411-433.

Via, S. 1994. Population structure and local adaptation in a clonal herbivore. Pages 58-85 in L. A. Real, editor. Ecological genetics. Princeton University Press, Princeton, New Jersey, USA.

von Ende, C. N. 1993. Repeated-measures analysis: growth and other time-dependent measures. Pages 113-137 in S. M. Scheiner and J. G. Gurevitch, editors. Design and anal- ysis of ecological experiments. Chapman \& Hall, New York, New York, USA.

Walker, B. H. 1992. Biodiversity and ecological redundancy. Conservation Biology 6:18-23.

Walker, B. H. 1995. Conserving biological diversity through ecosystem resilience. Conservation Biology 9:747-752.

Webster, K. E., T. M. Frost, C. J. Watras, W. A. Swenson, M. Gonzalez, and P. J. Garrison. 1992. Complex biological responses to the experimental acidification of Little Rock Lake, Wisconsin, USA. Environmental Pollution 78:73-78.

Wilkinson, L., M. Hill, and E. Vang. 1992. SYSTAT: Statistics. Version 5.2 edition. SYSTAT, Evanston, Illinois, USA

Williamson, C. E., R. S. Stemberger, D. P. Morris, T. M. Frost, and S. Paulsen. 1996. Ultraviolet radiation in North American lakes: attenuation estimates from DOC measurements and implications for plankton communities. Limnology and Oceanography 41:1024-1034.

Wu, L., and J. Antonovics. 1976. Experimental ecological genetics in Plantago II. Lead tolerance in Plantago lanceolata and Cynodon dactylon from a roadside. Ecology $\mathbf{5 7 : 2 0 5 - 2 0 8 . ~}$

Wyngaard, G. A. 1986a. Genetic differentiation of life history traits in populations of Mesocyclops edax (Crustacea: Copepoda). Biological Bulletin 170:279-295.

Wyngaard, G. A. 1986b. Heritable life history variation in widely separated populations of Mesocyclops edax (Crustacea: Copepoda). Biological Bulletin 170:296-304.

Yan, N. D., and R. Strus. 1980. Crustacean zooplankton communities of acidic metal-contaminated lakes near Sudbury, Ontario. Canadian Journal of Fisheries and Aquatic Sciences 37:2282-2293. 